NBER WORKING PAPER SERIES

\title{
EDUCATION, WELFARE, AND THE "NEW" FEDERALISM: STATE BUDGETING IN A FEDERALIST PUBLIC ECONOMY
}

\author{
Steven G. Craig \\ Robert P. Inman
}

Working Paper No. 1562

\section{NATIONAL BUREAU OF ECONOMIC RESEARCH 1050 Massachusetts Avenue Cambridge, MA 02138 \\ February 1985}

The research reported here is part of the NBER's research program in Taxation and projects in Government Budget and State and Local Public Finance. Any opinions expressed are those of the authors and not those of the National Bureau of Economic Research. 
Education, Welfare, and the "New Federalism:

State Budgeting in a Federalist Public Economy

\section{ABS TRACT}

President Reagan's proposal for a "New Federalism" raises a fundamental challenge to our current structure of Federal-state-local fiscal relations. This research examines the likely consequences of the New Federalism for fiscal allocations by state governments, and attempts to model the impact on both the size of state budgets and on the sectors on which that budget is spent. A political economy model of state budgeting is specified and estimated for a sample of forty-four states for the years 1966-1980. The analysis focuses on the two most visible sectors of state government expenditure, welfare and education, while accounting for the remaining end uses of state funds, other expenditure and taxes. Two general conclusions emerge from the analysis. First, current fiscal allocations by states are significantly influenced by the structure of Federal aid; without Federal matching rules and spending requirements stateswould choose to spend less on education and welfare services and more on tax relief and the numerous other state activities. Second, the New Federalism, as it relaxes the spending rules and reduces the level of Federal aid, both reduces state education and welfare spending and decreases the aggregate level of state expenditure. We conclude the New Federalism w111 succeed in reaching its objectives; the government sector will be more decentralized, with the additional consequence of reduced government budgets.

Steven G. Craig Department of Economics University of Houston University Park Houston, TX 77004 (713) $749-1362$
Robert P. Inman

National Bureau of Economic Research and Department of Finance University of Pennsylvania Philadelphia, PA 19104 
Education, Welfare and the "New" Federalism:

State Budgeting in a Federalist Public Economy

by

Steven G. Craig and Robert P. Inman*

\section{Introduction}

The United States public economy is a federalist economy. Public services are financed and purchased by Federal, state, and local governments each with autonomous decision-making authority, but each intinately connected to the others through an elaborate network of grants-in-aid and regulations. Historically, it has been an evolving structure marked by significant shifts in responsibilities and control. ${ }^{1}$ Most recently the trend in financial responsibility has been upward, towards the Federal level, while the state-local sector has become the primary provider of (non-defense) public services. 2 The decade 1965-1975, called the period of "creative federalism", marked a significant acceleration in those trends. During this period the number of Federal grants to the state-1ocal sector went from 160 separate aid programs in 1965 to 412 by 1976. Federal to state-1ocal aid grew from about $\$ 66$ per capita in 1960 to $\$ 192$ per capita in 1980 , both measured in 1972 dollars. 3 Almost all of these transfers imposed significant Federal regulation and spending requirements upon the recipient state and local governments; the one exception is General Revenue Sharing which composed only eight percent of all aid transferred in 1980. 
In January, 1982, President Reagan proposed a significant reform in our current fiscal structure. Under the label of the "new federalism", Reagan offered a three part reform package whose objectives are to decentralize fiscal choice through a consolidation of grants and a relaxation of Federal requirements, and to shrink the size of Federal government spending through a gradual reduction in overall dollar support. First, sixty-one Federal programs in education, community development, transportation, and social services will be returned to the states for state financing and administration. To help defray the costs of these programs a $\$ 28$ billion Federal trust fund supported by existing federal excise taxes will be established. The trust fund will be fully funded until 1988, at which time it will be reduced in four equal steps until, by 1992 , no additional federal support will be offered. However, the supporting Federal excise taxes will be discontinued as Federal taxes, and the states may, if they wish, institute these taxes as their own after 1992. Second, the Federal government will turn over to the states for state financing and administration the present Aid for Families with Dependent Children (AFDC) program. To help the states assume this financial obligation, the Federal government will, third, assume full financial and administrative responsibility for the current state-run and state-supported Medicaid program. As initially calculated, the dollars flowing to the states from the trust fund and the Federal assumption of Medicaid would just equal the added program costs to the states of AFDC and the sixty-one released Federal programs. The initial effects of the exchange would leave the fiscal structure basically unchanged; one redistribution 
program (Medicaid; health care for the poor) would be traded for another (AFDC) and block grants (the trust fund) would replace categorical aid (the sixty-one existing programs). In the long run, however, the Reagan administration hopes to "cap" and reform the current health insurance system (including Medicaid), to phase out the trust fund aid, and to foster interstate competition to discourage the growth of the state-local sector. If successful, the end result will be a more decentralized public sector and perhaps a smaller one as well.

Will the new federalism succeed? There is the first question, of course, of whether the new federalism will even emerge from Congress sufficiently intact to have its intended effects. We shall not make political predictions here. 4 In this paper, we are interested in the economic -- i.e., allocative -- consequences of Reagan's reforms assuming they do become law. Our work here extends our previous analysis of the new federalism (Craig and Inman (1982)) in two important directions. First, the previous work studied the effect of the fiscal reforms on one important state-local service, education. Here we include a second major program area -- welfare -- which is in many ways the linchpin of the new federalism. Secondly, in order to model two public services it is crucial that we specify how grants will influence both services and allow for the possibility of cross-effects between program areas. To do so we must specify more carefully than past research (our own included) just how multi-service fiscal allocations are decided. As in our prior work, however, we will continue to assume Federal fiscal policy is exogenously set and concentrate instead on the effects of that policy on fiscal choices in the 
state-local sector. It is from this analysis that we hope to understand the likely consequences of President Reagan's proposed reform of our current federalist fiscal structure.

\section{A Model of State-Local Fiscal Choice in a Federalist Economy}

From the early simple linear determinant models of state-local fiscal choice to the more recent median voter specifications, the emphasis in the empirical analysis of state-local budgetary allocations has been on voter preferences and the fiscal constraint which defines the set of feasible public budgets. Figure 1 illustrates the now familiar story.

One resident will be chosen as the representative or "typical" resident whose preferences for state and/or local services are decisive in the budgetary process. This resident's preferences are represented by a utility function over after-tax private income $(y)$ and public goods ( $g$ ), denoted $\mathrm{U}(\mathrm{g}, \mathrm{y})$, and are shown as a set of indifference curves in Figure 1. Public services ( $g$ ) are generally assumed to flow from a per capita sharing of a public facility ( $\mathrm{x}$ ) with a population of size $\mathrm{n}$ : $\mathrm{g}=\mathrm{x} / \mathrm{n}$. The public facility -- e.g., a park or school -- is produced by a constant-returns-toscale technology; $x$ costs $c$ dollars per unit. Total expenditures to provide a facility of size $x$ is $c x$. Residents may not be required to pay all of cx for these local services. In a federalist public economy, the Federal government often assists states and localities by either paying a fracion (m) of those total expenditures directly or by offering the locality a lump-sum payment (z) which can be used to cover local service costs. Residents therefore need pay 
Figure I: Resident Preferences and Budget Constraint

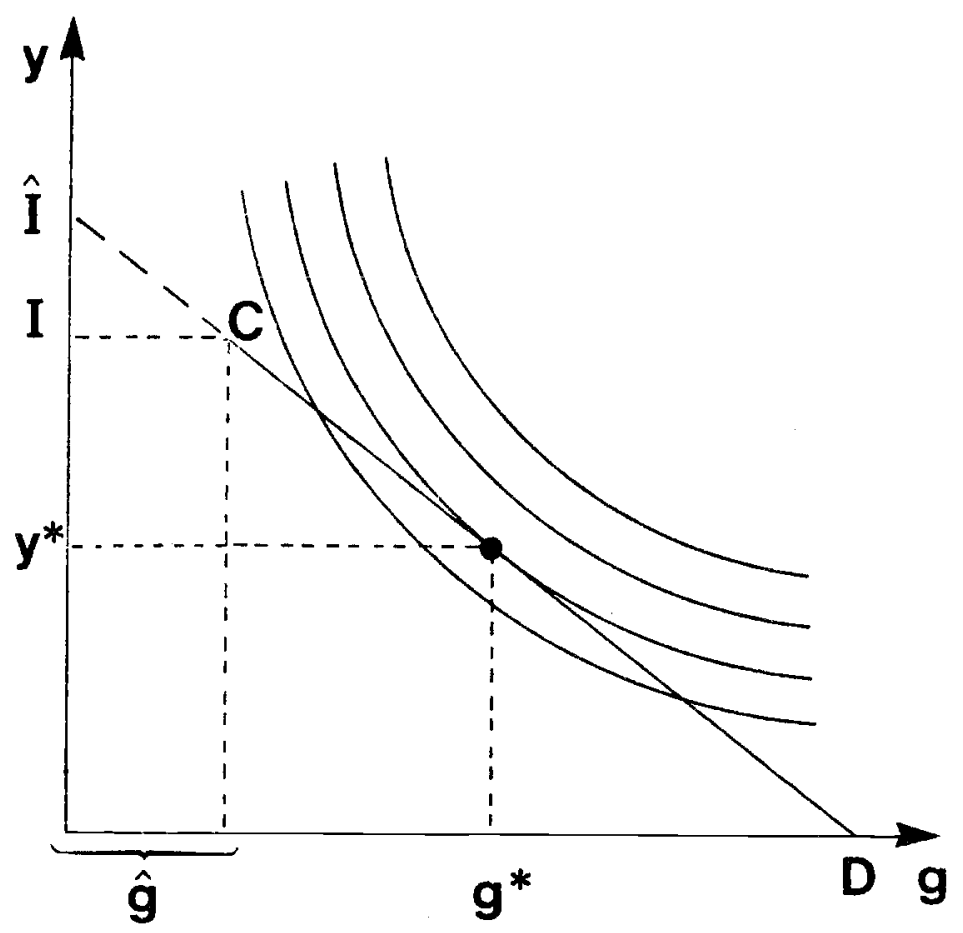


taxes which total only $(1-m) c x-z$, the government's net expenditure after deducting Federal "matching aid" ( $m$ is the matching rate) and Federal "lump-sum aid". The total tax payment -- $T=(1-\mathrm{m}) \mathrm{cx}-\mathrm{z}-\mathrm{w}$ - wll be shared by all residents within the community. If local taxes are proportional taxes, then each resident's share (denoted $\phi$ ) will equal the resident's share of his or her tax base (b) in the total tax base of the locality: $\phi=b /(B \cdot n)$, where $B$ is the aggregate tax base per resident in the locality. A typical local resident therefore pays a tax ( $t$ ) equal to:

$$
t=\phi T=(b / B)\{(1-m)(c x / n)-(z / n)\}, \text { or }
$$

since $g=(x / n)$ :

$$
t=(b / B)\{(1-m) c g-(z / n)\} .
$$

To define after-tax income for the typical resident, we simply subtract $t$ fron pre-tax income (I), with one further adjustment. Since most residents can deduct their state or local taxes from their Federal income tax payments, a dollar of local taxes will not cost the resident a full dollar. For each dollar of local taxes paid the resident saves a fraction, $q$, of that dollar in Federal tax payments, where $\mathrm{q}$ is the resident's marginal Federal tax rate. The portion of local taxes actually lost from pre-tax income will be $\pi=$ $(1-q)$. Net local tax payments are therefore $\pi t$, and after tax income, $y$, is equal to $I$ - $\pi$. This definition of $y$ allows us to define the typical resident's budget constraint when purchasing private goods (y) and public services $(g)$. From $y=I-\pi t$, and the definition of $t$, we have: 


$$
y=I-\{\pi(b / B)(1-m) c\} g+\pi(b / B)(z / n),
$$

or upon rearranging terms:

$$
y+p \cdot g=\hat{I}
$$

where $p$ is called the "tax price" of local public services and equals $\{\pi(b / B)(1-m) c\}$ and where $\hat{I}$ is called "full fiscal income" and equals $I+\pi(b / B)(z / n)$. The budget constraint is drawn in Figure 1 as the line ICD. The kink in the budget line at point $C$ reflects the fact that exogenous, lump-sum aid is generally restricted to be spent only on $g$ and cannot be given directly to households; points along the dashed extension of the budget line to I are not legally available to the typical resident. From the point-ofview of the resident, lump-sum aid is equivalent to a free gift of $\hat{g}$ units of the public good. 5 From point $c$, the resident is then free to buy additional units of $g$ at a "tax price" of $p \quad\{=\pi(b / B)(1-m) c\}$ dollars per unit of $g$.

The preferred allocation of the representative resident will be that combination of $g$ and $y$ which maximizes $U(g, y)$ subject to the constraint. This is point $\left(g^{*}, \mathrm{y}^{*}\right)$ in Figure 1. As is true in most economic models of this form, an increase in full fiscal income $(\hat{I})$ or a fall in the price of $g$ (p) will stimulate the resident's demand for the public good. $\hat{I}$ rises either because before-tax income increases (I) or lump-sum aid per capita increases $(z / n)$. The price, $p$, falls either because costs (c) fall, or the matching rate (m) rises, or more local taxes become deductible ( $\pi$ falls), or there is an exogenous increase in the average level of the locality's tax base (B 
rises). The effects of change in each of these variables is captured in the representative resident's demand curve for public services:

$$
g=f(p, \hat{I} \mid \text { Tastes })
$$

where the comparative statics of price and income changes (normally) predicts $\partial g / \partial p<0$ and $\partial g / \partial \hat{I} \geqslant 0$. The taste variables (Tastes) are assumed to be those of the "typical" resident who is decisive in budgetary allocations.

This specification of state-1ocal fiscal choice has been used extensively to analyze allocation in a federalist economy; see Inman (1979) for a review. However, there has been one matter left unresolved in almost every application of this approach. Who exactly is the typical resident whose demand curve is estimated? Vague, but generally unsubstantiated, references to some average income voter is seen to suffice. Only recently have there been efforts to give a precise answer to this important question. That 1iterature draws its inspiration from the classic paper of Howard Bowen (1943) on the role of the median voter in fiscal politics. 6

In the special case where only one public service level is being decided and decisions are made by a simple majority rule process -- school spending by local districts is the usual example -- the political process will select that level of services preferred by the voter with the median (50th percentile) demand for the public good. If a service level greater than that demanded by the median voter is offered, the median voter and all voters with lower demands will vote against it. If a service leve1 less than that demanded by the median voter is offered, the median voter and all voters with higher 
demands will vote against $1 \mathrm{t}$. That level of services demanded by the median voter will defeat all other service levels in majority rule comparisons. The median demand voter is decisive and becomes the natural candidate for the "typical" resident in the economic model of fiscal cholce.

Tests of the median voter model against recent experiences of U.S. and European local governments support at least two of the model's central predictions: the demand for local services declines as the median voter's tax price increases $(\partial g / \partial p<0)$, and the demand for local services increases as the median voter's full fiscal income rises $(\partial g / \partial \hat{I}>0) ?^{7}$ Yet one central prediction of the model is rejected. The two components of full fiscal income -- private income (I) and lump-sum aid per capita $(z / n)$-- should have identical effects on local service demands if $\pi(b / B) \equiv 1$, alternatively if $\pi(b / B)<1$ the effect of income should be greater than the effects of exogenous aid. 8 In fact, the empirical evidence is uniformly against this proposition: $(z / n)$ has almost always had a larger impact, sometimes a 20 times larger impact, on local service demands than $I$. The large effect of aid on local service demand compared to the small effect of income has been called the "flypaper effect". Since private income belongs initially in private hands and public aid is given initially into public hands, it appears that dollars "stick" where they first land. Yet the demand model predicts dollars are fully transferable between public and private uses. Something more than the demand model is needed if we are to rationalize these empirical results. That something more is politics. "The existence of a "flypaper effect" implies the presence of a wedge between what fully informed, utility maximizing residents would prefer and what they finally receive from the 
state-local fisc. They would prefer to have lump-sum aid spent as private income; what they get is lump-sum aid spent almost entirely on public services. Who or what is that wedge which stands between public allocations and resident preferences? Romer and Rosenthal (1979; 1982 with Filimon) have argued that it is a budget-maximizing politician-bureaucrat -- a "typical" state-local official -- who is insulated from resident control. A desire to maximize the public budget means the bureaucrat-politician wants to spend all aid. 10 Insulation from voter control gives him the freedom to do so. In essence, what Romer and Rosenthal have done is introduce a second player into the game of fiscal choice -- a "typical" state-local official -- whose preferences for how public dollars are allocated differs dramatically from the preferences of our first player -- the "typical" resident. We have a conflict which must be resolved. It is politics, the process of conflict resolution, which will balance these competing interests, and it is the analysis of politics which is so far missing from our formal models of fiscal choice.

The Romer-Rosenthal analysis sees the public allocation process as a bargaining game between the politician-bureaucrat and the resident voter. The voter retains the ultimate right to veto any budgetary proposal but the politician retains the right to offer proposals. The game is played a finite number of times and if no agreement is reached, a "reversion level" or fall-back budget is automatically adopted. Politicians and voters can talk to each other -- there are budget hearings -- and they will seek to strike the best compromise subject to the rules of bargaining. The model predicts two outcomes which can distinguish it from the strict, resident-only demand model: 
(1) lump-sum aid and private income need no longer have identical effects, and

(2) the compromise will likely balance the competing interests of the typical voter and the typical state-local official. ${ }^{1}$ The empirical evidence is supportive of both predictions. First, Filimon, Romer, and Rosenthal (1982) find a significant flypaper effect -- like most other studies of local budgeting -- which they attribute to the inability of voters to monitor what public officials do with lump-sum aid (a "fiscal illusion"). Second, they find the bargaining process between the voter and the bureaucrat leads to a local budget which is approximately $15 \%$ larger than that desired by the median voter were he or she decisive alone.

While one need not embrace all the details of the Romer-Rosenthal analysis, their basic point seems hard to ignore. Politics matter. They have introduced the state-local official as a second player along with the utility maximizing resident voter into the game of state and local fiscal choice. Each player is given the "right-to-play" and they must negotiate an outcome. Suddenly, not just preferences and a budget constraint determine local fiscal allocations; the rules of the game matter too. Who are the players? What is their standing and their rights within the budgetary game? How will conflicts be resolved? These are political questions and they require political analysis for answers. The simple analytics of budgetary choice so neatly captured by equation (1) will be inadequate when policy choices involve many players and many possible public programs.

Yet the formal analysis of conflict resolution within a democratic process faces a troubling contradiction of theory and fact. In his famous 
(Im)possibility theorem, Kenneth Arrow (1963) proves that there is no democratic process involving more than two players and more than two options which would always yield a determinate outcome. Either matters are indeterminate -- essentially "cycling" from one policy option to another -- or there is a dictator who decides the final allocation. Only in very special and unlikely circumstances (P1ott (1967) and Kramer (1973)) will it be theoretically possible for a democratic choice process to give a determinate outcome. No-equilibrium is the most likely result. Yet as a factual matter, our democratic fiscal system does arrive at equilibrium allocations of services and taxes. How can we resolve this apparent conflict of theory with the facts? The answer must lie in a richer theory. Recent advances in the theory of political institutions provides us with what we need.

Figure 2 illustrates the central analytic problem for the simple case of two fiscal options -- e.g., spending on education $\left(g_{1}\right)$ and welfare $\left(g_{2}\right)--$ and three coalitions -- e.g., poor (P), rich (R), and middle class (M) voters. Each coalition is assumed to have well-defined preferences over $g_{1}$ and $g_{2}$. These preferences differ, however, and a conflict arises which must be resolved. The poor want large welfare expenditures and relatively low education outlays. The rich want modest welfare expenditures and large education outlays. The middle class are assumed to want modest expenditures on education and low welfare outlays. ${ }^{12}$ The conflict resolution process is assumed to be a democratic majority rule process in which each coalition has one equal vote. $^{13}$ Coalition preferences are represented by a "bliss point" or an ideal allocation -- points $P, R$, and $M--$ and a set of indifference curves 
Figure 2: Majority Rule Disequilibrium

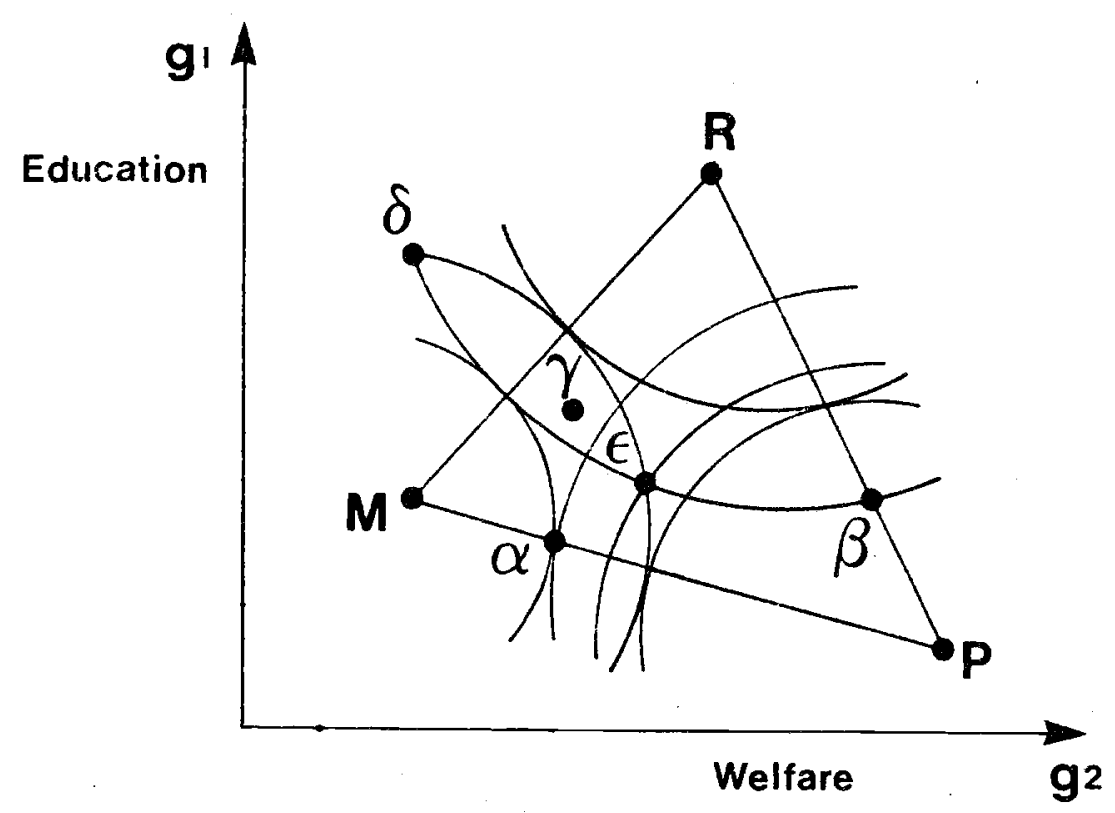


about the bliss points representing decreasing levels of well-being as we move away from the ideal allocation. The indifference curves are depicted as circular for simplicity. The solid lines connecting the bliss points are the "contract lines" marking the tangencies of the indifference curves between the various pairs of coalitions. The area within the three contract lines defines the set of Pareto points for this allocation problem. A move from an allocation within the Pareto set (e.g., point $\varepsilon$ ) to a point outside the set (e.g., point $\delta$ ) will make members of at least one coalition worse off (e.g., coalition P). Conversely there is always a point within the Pareto set (e.g., point $\gamma$ ) which will make all voters better off compared to its alternative outside the Pareto set (e.g., point $\delta$ ). The important point, however, is there is no stable majority rule winner in this game. As any point outside the Pareto set will be defeated unanimously by some point within the set, we can focus our analysis on alternatives such as $\alpha, \beta, \gamma$, and $\varepsilon$. In pairwise comparisons by majority rule, $\beta$ (favored by $P$ and $R$ ) beats $\alpha$ (favored by $M$ ), $\alpha$ (favored by $M$ and $P$ ) beats $\gamma$ (favored by $R$ ), but now note that $\gamma$ (favored by $M$ and $R$ ) beats $\beta$ (favored by $P$ ). Point $\varepsilon$ which is inside the Pareto set is also caught in a voting cycle. Point $\varepsilon$ wins over point $\alpha$ as voters $P$ and $R$ prefer $\varepsilon$; point $\alpha$ defeats $\gamma$ as $M$ and $P$ prefer $\alpha$; but $\gamma$ beats $\varepsilon$ as $M$ and $R$ prefer $\gamma$. There is no equilibrium winner among the alternatives in Figure 2.

To obtain an equilibrium outcome for this allocation game, further political structure in addition to majority rule is needed. Shepsle (1979) has described and analyzed various legislative institutions which are sufficient to produce stable, majority rule allocations. The final 
allocations in a Shepsle equilibrium -- often called a structure-induced equilibrium --are conditioned by the status quo and the constitutional rules which determine legislative structures. Shepsle adds three new structural features to the majority-rule allocation game: (1) a committee structure which identifies who is allowed to offer proposals for consideration by the full legislature; (2) a jurisdiction structure which defines which proposals may be considered by the committee and the legislature; and (3) an amendment structure which describes how the committee's proposals to the legislature may be altered. Together, these three additional rules can insure a stable allocation.

Figure 3 illustrates one possible case. The committee structure identifies that group which is permitted to submit proposals for consideration; assume for the example it is group $R$, the rich. In Figure 3 the jurisdiction structure limits voters to consider only education proposals; if $\left(\hat{g}_{1}, \hat{g}_{2}\right)$ is the status quo point (denoted $\beta$ ), only policies along the line at $g_{2}=\hat{g}_{2}$ can be considered. ${ }^{14}$ The amendment structure permits voters to consider only the committee's proposal against the status quo; the amendment process is "closed." 15 Group $R$, which we call the "agenda-setter" in this example, will propose the $g_{1}$ alternative along the line at $\hat{g}_{2}$ which maximizes $R^{\prime}$ s utility subject to the constraint that it will be approved by a majority in a pairwise comparison with the status quo point. $R$ needs one more vote in addition to its own. That vote will come from the middle-class (M), and the final allocation will be at point $\varepsilon^{*}=\left(g_{1}^{*}, \hat{g}_{2}\right)$. Point $\varepsilon^{*}$ is just inside $M^{\prime} s$ indifference curve through the status quo -- the position needed to win M's support -- and is the best that $R$ can do as an agenda-setter subject to these 
Figure 3: Single Jurisdiction Equilibrium

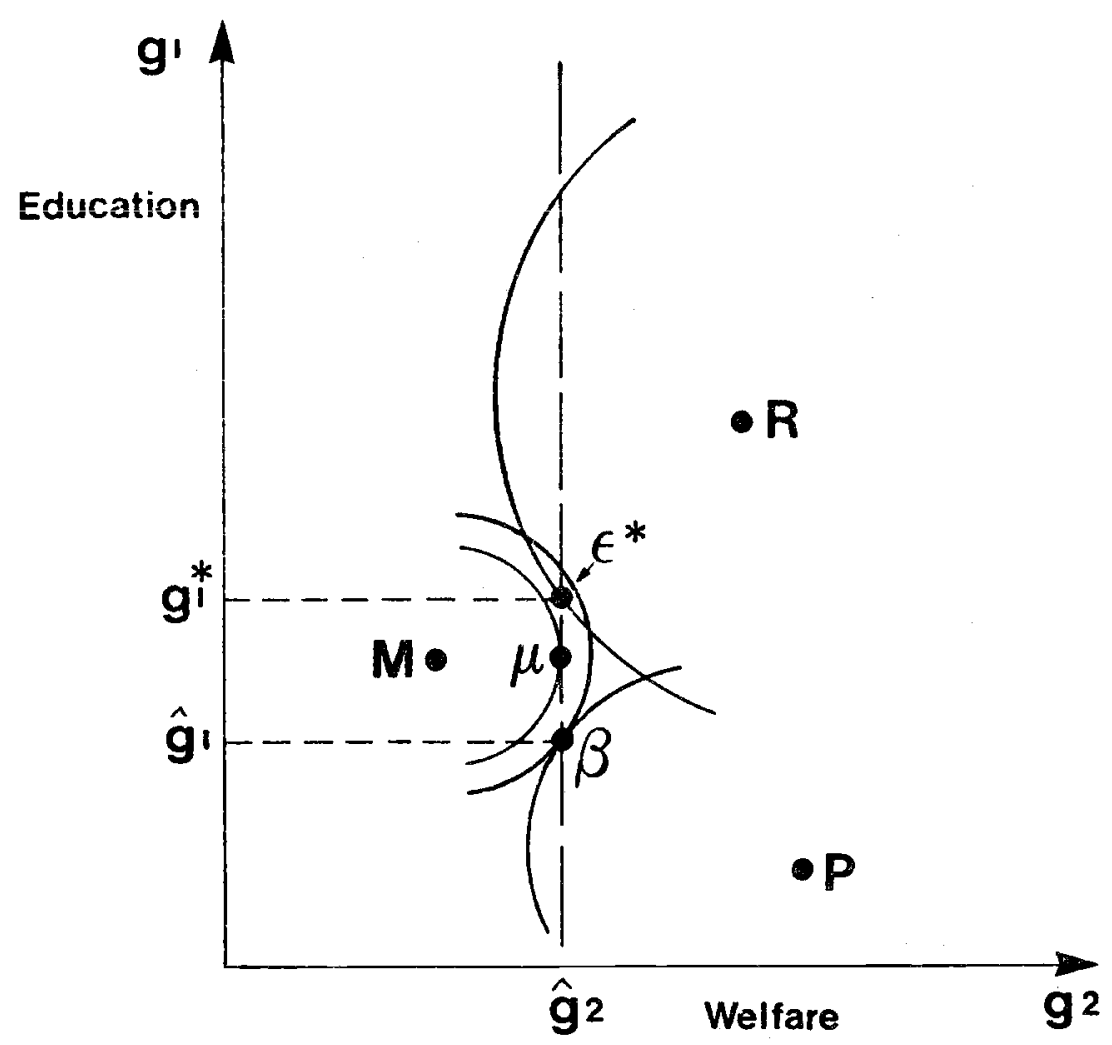


structural constraints. If group $M$ were the agenda-setter from the committee structure, the final equilibrium would be at point $\mu$ with $M$ and $R$ voting for approval and the poor $(P)$ against. If $P$ were the agenda-setter, the final allocation would remain at the status quo point, $B$, for group $P$ could not do better and still win the support needed from groups $M$ or $R$ to defeat $B$.

Figure 4 extends the analysis to a case where the jurisidiction structure allows the committee and the voters to consider both dimensions of fiscal choice simultaneously. Again, allow $R$ to be the agenda-setter and point $\beta$ to be the status quo. R seeks, as before, to maximize its utility subject to the structural constraints and the status quo. $R$ can attract group $P$ into a majority winning coalition with any proposal along the contract line between points $P$ and $\delta_{0}{ }^{16}$ Group $P$ is just indifferent between the status quo and proposal $\delta$; allocations closer to point $R$ along the contract line (which group $R$ prefers) will be rejected by $P$ in favor of $B$. If $R$ chooses to align with group $M$, points along the $R$ to $M$ contract line between allocations $\gamma$ and $\varepsilon^{* *}$ are available; allocations between points $M$ and $\gamma$ are rejected by group $R$ while allocations between $R$ and $\varepsilon^{\star *}$ are rejected by group $M$. Therefore, the possible winning allocations available to agenda-setter $R$ are on the heavy line segments $\gamma \varepsilon^{\star *}$ and $P \delta$ in Figure 4. $R$ will select that allocation on one of these line segments which maximizes the coalition's utility; e.g., allocation $\varepsilon^{\star *}$ in Figure 4. In this example, policy is set by the middle and rich coalitions. A sintlar analysis will show that point $P$ is the winning allocation if group $P$ is the agenda-setter and that point $\gamma$ is the winning allocation if group $M$ is the agenda-setter. All three allocations are stable 
Figure 4: Open Jurisdiction Equilibria

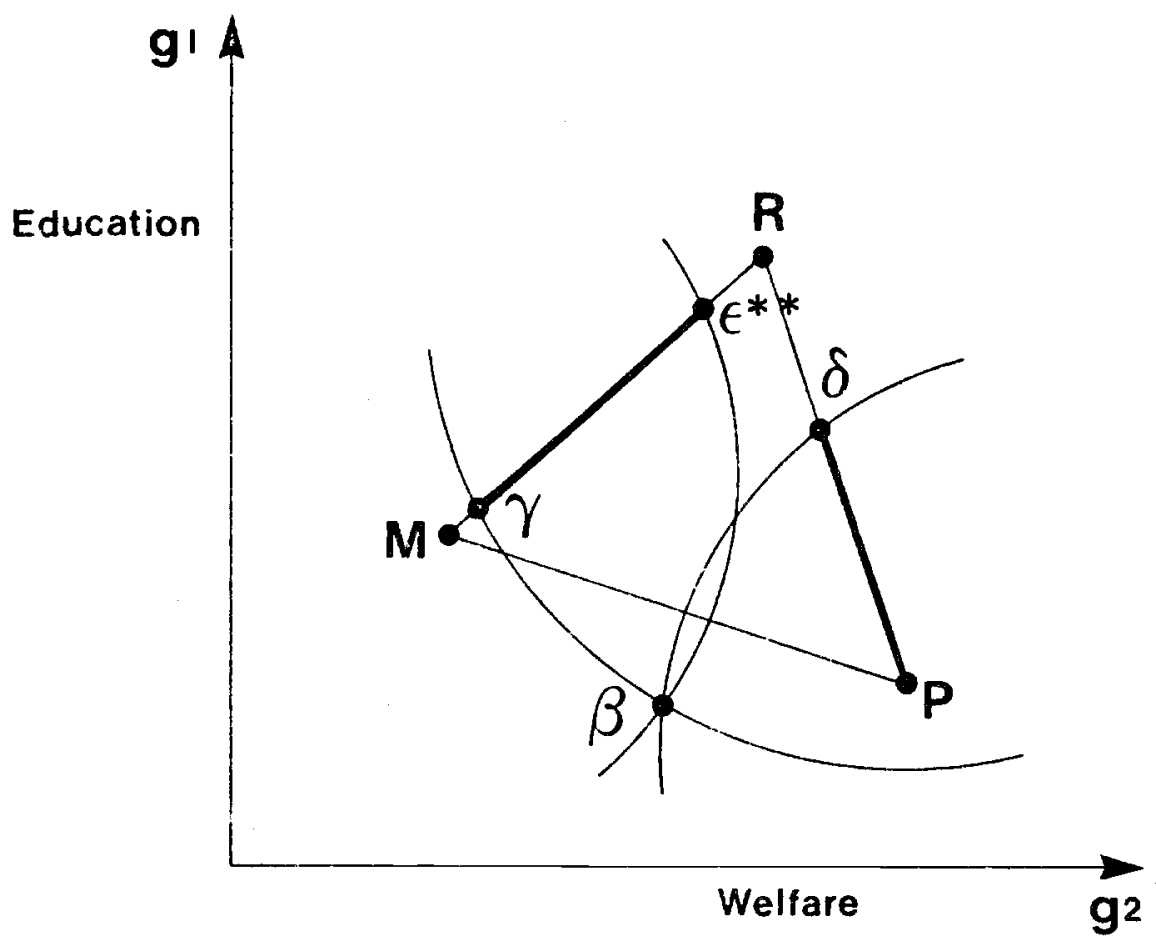


equilibria provided the political structure, including the status quo point, remains fixed. 17

The concept of a structure-induced equilibrium provides an important element in the needed theoretical framework to begin the analysis of fiscal allocations in a federalist economy. Since budget allocations are stable over time, it is essential that we have a theory of political choice which gives a well-defined equilibrium prediction. Further, the theory must generate equilibrium outcomes even when there is conflict and the issues are multidimensional. The theory of structure-induced equilibria does just that. To apply the theory of structure-induced equilibria, however, we must close two gaps in the analysis. First, we must specify the determinants of voter preferences in the policy space from a general, underlying preference structure over public and private goods: Second, the political theory is a partial equilibrium theory providing predictions of budget allocations given the status quo point and the relevant political institutions. Applications of the theory of structure induced equilibrium must specify which institutions are relevant and exactly how those institutions will influence budgetary choices.

The starting point for the specification of voter preferences over fiscal policies is the individual utility maximization model of fiscal choice which defined the individual voter demand curves in (1). ${ }^{18}$ Generalized to the case of multiple public goods $(t=1, \ldots, G)$, the utility-maximizing demand model would define a vector of preferred allocations, the typical element of which is $g_{t}=f\left(p_{1}, \ldots, p_{G}, \hat{I} \mid\right.$ Tastes $)$. The optimal leve1 of private goods (y) will be what is left over after the resident pays for the preferred bundle of public goods. For each voter or coalition, the vector of preferred public 
allocations defines the voters' bliss points -- e.g., points $R, M$, and $P$, in Figures 3 and 4 for the case of two public goods. 19 The starting point for specifying the influence of political institutions on budgetary choices is the fact that in models of structure-induced equilibria final allocations will be weighted averages of the (just specified) voter bliss points -- e.g., points $\varepsilon^{* *}, \gamma$, or $P$ in Figure 4. The institutional structure -- status quo, committee, jurisdiction, and ammendment structures -- will define the weights. If we allow $S$ to represent political structure and $\beta$ the status quo point, then the final budgetary allocations of public goods can be specified as:

$$
\begin{aligned}
g_{t}^{*}= & \alpha^{R}(S, B) \cdot g_{t}^{R}\left(p_{R}, \hat{I}_{R} \mid \text { Tastes }\right)+\alpha^{M}(S, B) \cdot g_{t}^{M}\left(p_{M}, \hat{I}_{M} \mid \text { Tastes }\right) \\
& +\alpha^{P}(S, B) \cdot g_{t}^{P}\left(p_{P}, \hat{I}_{P} \mid \text { Tastes }\right) \quad(t=1, \ldots, G)
\end{aligned}
$$

where $p_{i}$ is the vector of tax prices, $\hat{I}_{i}$ is the full fiscal income respectively of each voter group $i(=R, M, P)$ and where $\alpha^{R}(\cdot)$ is the political weight on the rich coalition, $\alpha^{M}(\cdot)$ is the political weight on the coalition of middle class voters, and $\alpha^{\mathrm{P}}\left(\equiv 1-\alpha^{\mathrm{R}}-\alpha^{\mathrm{B}}\right)$ is the political weight on poor voters. Variables which might be included in the vector of political structure include controlling interests (chairmanship, majority) of the key legislative committees which set the agenda, jurisdiction and budgetary rules on how dollars can be allocated, size of voting blocs within the legislature or community, political allegiance of those with veto power 
over final allocations (e.g., governor, mayor), and amendment rules which might allow proposals to be submitted from at-large interests. 20

Once estimated, equation (2) gives us exactly what is needed to begin to analyze the effects of changes in public dollars and political structures on fiscal allocations in a federalist economy. Section III outlines one application of this methodology to state government spending for welfare, education, and "other services".

\section{State Spending for Education, Welfare, and "Other" Services}

President Reagan's new federalism offers a fundamental reorganization of our current federalist fiscal economy, decentralizing many of the new Federally mandated fiscal activities of the state and local sector. Central elements in the reform are the current Federal aid programs in education and public welfare. These programs now constitute 49.5 percent of all federal to state-1ocal assistance. It seems useful, therefore, to begin our analysis of fiscal allocations in a federalist economy by focusing on a major, new reform package and on the central components of that package. We do so by specifying and estimating a four-equation budgetary model of state allocations for education, welfare, "other services", and reverues. The model is based upon the conceptual analysis of fiscal choice summarized by equation (2) above, and is estimated for a sample of the 48 mainland states over the period 1966-1980. Three voter coalitions -- a rich/upper middle cluss ( $R$; defined as the percent of families with income $>\$ 25,000)$, a middle class (M; percent of families with incomes between $\$ 5,000$ and $\$ 25,000)$, and a poor class ( $P$; 
percent of families with incomes less than $\$ 5,000)$-- are assumed to determine state budgetary allocations over three expenditure categories and non-debt, current state revenues (SREV). Expenditures include state aid to local elementary-secondary education ( $\mathrm{SAE}$ ), state payments to low income famllies from all state-run welfare programs (SWL), and "other" current account. state expenditures (OEXP). SAE includes all direct state to local educational aid as well as all Federal education aid given to the states with the requirement that it be "passed-through" to the local units. SWL Includes state AFDC payments, state Medicald payments, state general assistance payments, and the many small state-run supplemental welfare programs. All Federal aid dollars which are given directly to the states to help defray these welfare costs are included in SWL. OEXP includes all other state expenditures supported from non-debt state revenues (SREV), while SREV Includes all state tax revenues as well as revenues from state user fees and 1 icenses. The model is specified as four behavioral equations and a current acccints budget identity:

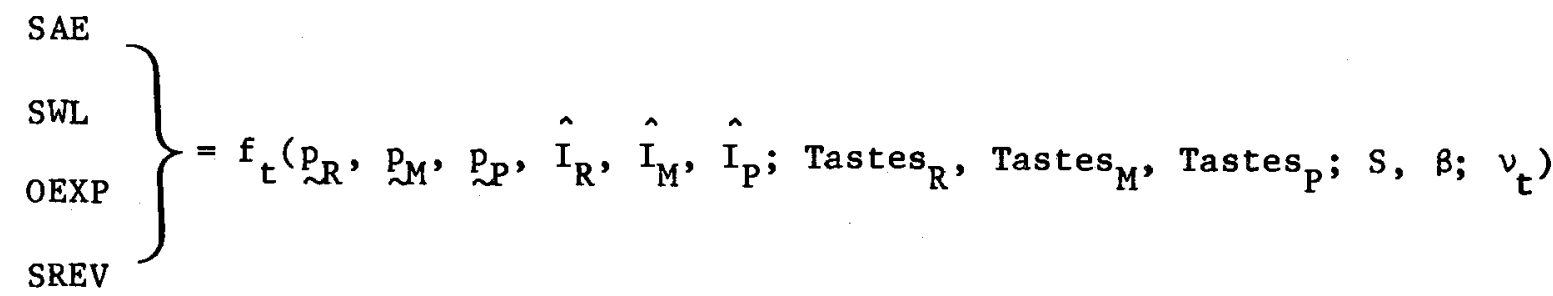

where $t=S A E, S W L, O E X P, S R E V$, and

$$
\begin{aligned}
& \mathrm{SAE}+\mathrm{SWL}+\mathrm{OEXP} \equiv(1+\phi e) \mathrm{S} E \mathrm{EV}+\mathrm{LSGRS}+\mathrm{LSEA}+\mathrm{CEM}+\mathrm{m} \theta \mathrm{SWL}+ \\
& \text { LSWA + OFA, }
\end{aligned}
$$


where tax prices $\left(\mathrm{p}_{i}, i=R, M, P\right)$, full fiscal income $\left(\hat{I}_{i}, i=R, M, P\right)$, voter tastes (Tastes $\left._{i}, i=R, M, P\right)$, the political structure $(S)$ and the budgetary status quo $(\beta)$ are defined as in our previous discussion of equation (2) above, and where $\nu_{t}$ captures the effects of all unmeasured determinants of SAE, SWL, OEXP, or SREV. Equation (4) is the state's budget identity which relates total expenditures to total current account revenue from the state's own revenues and from the Federal-to-state grants-in-aid. Our analysis provides a careful disaggregation of the effects of Federal aid; these aid programs are central to our understanding of fiscal allocations in a federalist economy and to predicting the likely effects of the new federalism. Disaggregated Federal assistance includes: (1) Federal general revenue sharing measured by the program's two component parts -- a lump-sum, general revenue sharing grant (LSGRS) and a tax effort component which gives states more money (at a rate, e) for each dollar raised from a state income tax (which constitutes the share $\phi$ of total state revenues); ${ }^{21}$ (2) lump-sum education aid (LSEA, including Elementary and Secondary Education Act, Title I for the educationally deprived, Title VI for the handicapped, and vocational education aid); (3) closed-ended matching aid for education and welfare (CEM, including school lunch, breakfast, and milk programs and all low-income commodity assistance aid); (4) open-ended welfare matching aid at the federal matching rate $m$ for eligible expenditures (AFDC and Medicald outlays are eligible for matchin; aid and constitute a share $\theta$ of SWL); (5) lump-sum welfare aid (LSWA, including aid for social services, child nutrition, maternal and child health care); and (6) other federal aid for current 
expenditures (OFA, excluding highway construction aid but inclusive of other Federal-to-state aid not already included in revenue-sharing, education, or welfare aid). Since the budget identity defines an exact relationship between each of the three expenditure categories -- SAE, SWL, and OEXP - and own state revenues (SREV) given Federal-to-state aid, we need only estimate three of the four behavioral equations in (3). We choose to estimate the SAE, SWL, and SREV equations and infer OEXP from the budget identity.

The estimation of the SAE, SWL, and SREV equations requires the approximation of several of the independent variables in (3). Specifically, we do not have individualized tax prices or individualized full fiscal incomes for the rich, middle class, and poor coalitions, nor do we have measures of the determinants of coalition tastes. We do have measures of the components of those tax prices and fiscal incomes, and plausible correlates with coalition preferences. Coalition tax prices have two elements: open-ended Federal matching aid programs, and relative population usage. The open-ended matching programs are revenue sharing (e) and welfare (m); while relative population usage of education services is measured by the percent of school age children who attend private schools (PRIV), and population usage of welfare is measured by the percentage of families whose head is over 65 (OLD), or is headed by a female (FHH)..$^{22}$ Per capita state income (INC), exogenous Federal ald to state governments (LSGRS, LSEA, CEM, LSWA, OFA), exogenous Federal aid to local governments (educational impact aid (IMPA) and low income housing aid (LHA)), and Federal assistance given directly to households (earned income tax credit (EITC) and food stamps (FS)), are used to spectfy, 
collectively, the coalitions' full fiscal incomes. ${ }^{23}$ Two vartables are Included to specify coalitions' tastes for education -- percent high school graduates (HS) and the average number of children per family (KIDS) -- and three variables are used to measure coalitions' tastes for low-income assistance including the exposure to poverty or to the risks of poverty -percent of population in urban areas (METRO), the state unemployment rate (UE), and percent of state population employed in manufacturing (MAN).

Political structure is defined by the percent of the population in each voter coalition -- $R$ and $P$, with $M$ omitted from the regressions to avoid singularity -- and by the percent of population which is white (WHT) as a proxy for possible political discrimination and/or relative voter participation. We also include a vector of state dummy variables to control for the many institutional differences in the budgetary process across states. $^{24}$ Finally, the state's budgetary status quo is represented by a lagged vector of educational services provided -- lagged school personnel per public school enrollee $\left(\mathrm{PER}_{-1}\right)$, lagged wages per public school employee $\left(\right.$ WAG $\left._{-1}\right)$, and lagged non-personnel expenditures per public enrollee (NPEXP -1 ) -- and by lagged state welfare expenditures per capita (SWL, ). All fiscal variables and state income are measured in per capita units and are deflated by a state cost of living index. 25

The error term specification of our model assumes that our state dumny variables will capture all systematic effects across states which are correlated with the included exogenous variables. Previous analysis (Craig-Inman, 1982) suggests that a time trend may also be appropriate with 
this sample to control for the systematic upward drift in state spending. With both state dummy variables and a time trend included as exogenous variables we feel that the remaining unmeasured determinants of taxes and spending captured by $\nu_{t}(t=S A E$, SWL, and SREV $)$ are randomly distributed across states and time. This least squares dummy variable estimation procedure has been shown to closely approximate two-way error components estimation (see Baltagi (1981)). We do, however, permit error term interdependence across revenue and spending within states and years. Such cross-equation interdependence is to be expected in budgetary models; estimation by generalized least squares (GLS) is appropriate. 26

The model as estimated is clearly a reduced-form specification of the structural model given in equations (3) and (4). Thus, we cannot identify the relative importance of the various coalitions in state budgetary policy, nor the exact role political structure plays in setting spending or taxes. We can, however, identify the effects of Federal aid on state budgetary outcomes, and that is our central concern here. ${ }^{27}$ Section IV summarizes our results based upon GLS estimation of the budget model.

\section{State Fiscal Policy}

Table 1 summarizes our estimates of a state budgetary model for state assistance for education ( $\mathrm{SAE}$ ), state welfare spending (SWL), state revenue (SREV), and, via the budget identity, other state expenditures financed from current revenues (OEXP). The results across all three estimated equations te11 a consistent, and upon reflection a not too surprising, story: education 
Table 1

GLS Estimation Results

Variable

CONSTANT

$\ln ($ LSGRS)

e

LSEA

CEM

CEM* INC

m

$\mathrm{m} * \mathrm{INC}$

LSWA

OFA

$\ln (\operatorname{EITC})$

FS

IMPA

LHA

INC

OLD

PRIV

FHH

HS

KIDS

METRO

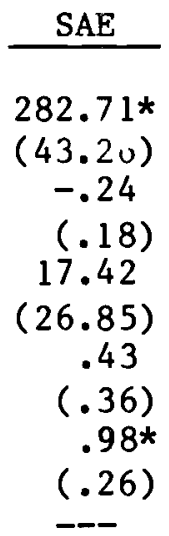

$35.71 *$

(16.86)

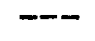

$-.20 *$

$(.08)$

$-.16 *$

$(.07)$

$1.37 *$

(.28)

.34

$(.22)$

1.16

(.98)

$-.76$

(.51)

.0033

(.0034)

72.12

(206.39)

$-12.78$

(17.46)

$-7.98 *$

(1.22)

-263.28 *

(91.35)

$-5.53$

(8.01)

$-25.16$

(17.68)
SWL

33.33

(25.00)

$-.25 *$

(.10)

$-36.48 *$

(1.5.52)

.23

(.21)

.05

(.15)

$-22.95 *$

(9.74)

.076

(.048)

$-.06$

$(.04)$

$.74 *$

(.16)

.12

(.13)

$.95 *$

$(.57)$

$-.32$

(.29)

$.0078 *$

(.002)

$-43.11$

(119.27)

1.00

(10.09)

$-2.85 *$

(.70)

6.03

(52.78)

16.29*

(4.63)

5.48

(10.22)
SREV

290.13*

(76.95)

.26

(.30)

$-14.34$

(46.09)

$-.39$

$(.60)$

.61

(2.14)

.00035

(.00069)

$-30.05$

(50.71)

$.024 *$

(.014)

$-.12$

(.14)

.005

(.12)

$1.47 *$

(.47)

$.69 *$

(.37)

3.24*

(1.63)

.12

(.85)

$.025 *$

(.008)

$-346.94$

(345.78)

$-4.98$

(29.15)

$-9.17 *$

(2.14)

-312.30 *

(152.42)

27.77*

(13.34)

$-70.35 *$

(29.53) 
Table 1 (continued)

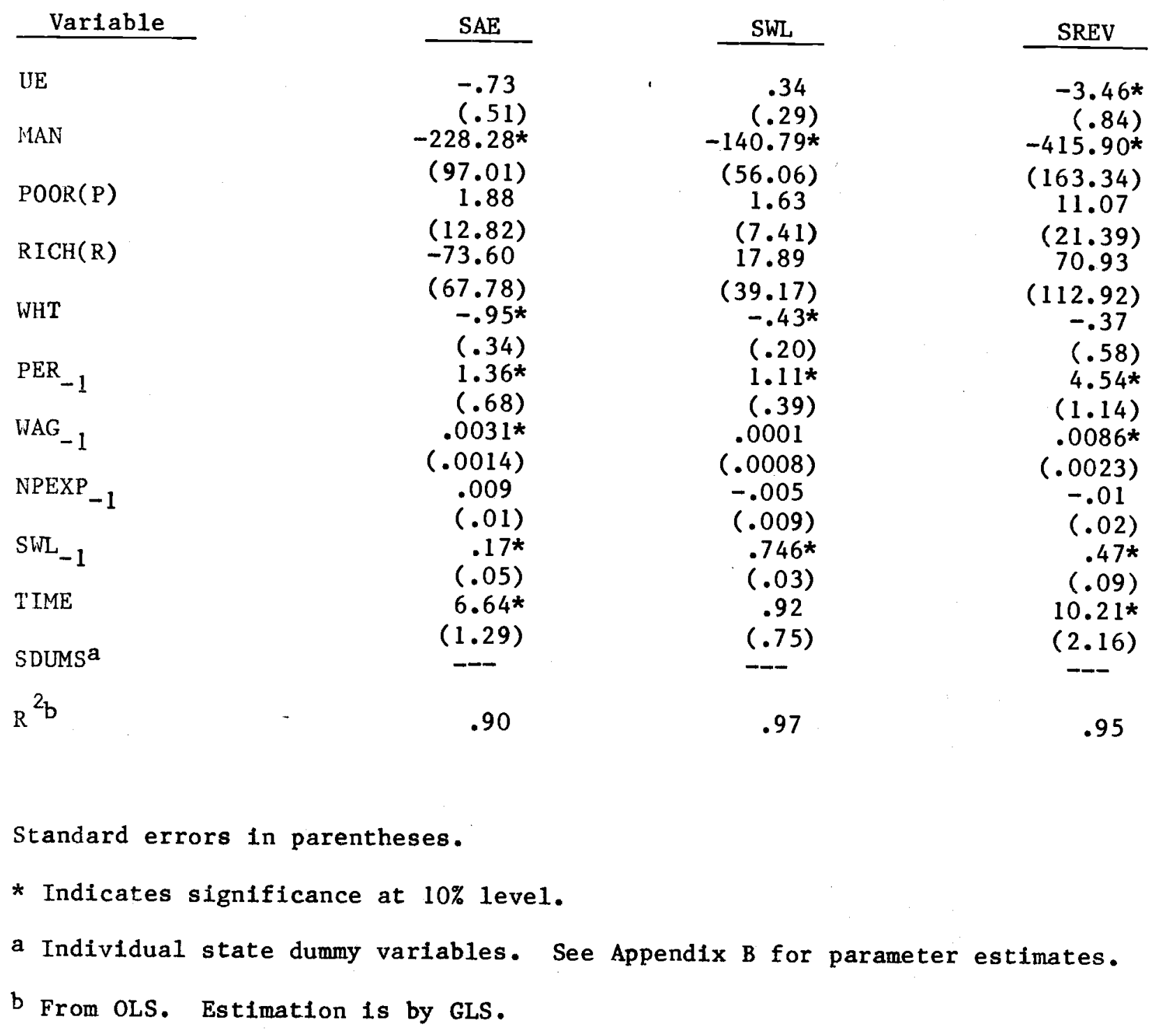


assistance, welfare spending, and broad-based tax relief are not the favored outlets for state dollars. State politicians prefer to spend state public dollars on OEXP, the treasure chest of many small, favored public projects which keep constituents from all corners of the state content. If the Federal government wishes to stimulate state spending on human services -- education and low income assistance -- it must impose strong spending regulations and matching requirements on Federal aid, and even these requirements will not keep some dollars from leaking into OEXP.

Nothing reveals this pattern more clearly than an analysis of the initial impact effects of the major Federal-to-state aid programs, beginning with the least restrictive grant -- general revenue sharing -- and moving to the most regulated grant, -- open-ended categorical matching aid.

(1) General Revenue Sharing. The marginal effects of a dollar of lump-sum revenue-sharing aid (LSGRS) on each of the two estimated expenditure items -- SAE and SWL -- are negative and, in the case of SWL, statistically different from zero. Estimated at the mean value of LSGRS (=\$2.84/capita), a dollar of GRS aid will reduce state education aid by $\$ .08$ and state welfare spending by $\$ .09$. LSGRS is estimated to increase state revenues by $\$ .09$, but the effect is not statistically significant. OEXP is clearly the net recipient of GRS funds. From the budget identity -- eq. (4) -- we can estimate the average effect of a small change in LSGRS on OEXP as: $\triangle$ OEXP = $\triangle \mathrm{LSGRS}-\Delta \mathrm{SAE}-(1-\mathrm{m} \theta) \Delta \mathrm{SWL}+(1+\phi \mathrm{e}) \Delta \mathrm{SREV}=1-(-.08)-(.4)(-.09)+$ $(1+.01)(.09)=\$ 1.21 .^{28}$

The "tax effort" component of revenue-sharing (e) has only tiny effects on the state budget; the estimated coefficients are insignificant, except for 
Table 2

Equilibrium Effects of Federal Aid

\begin{tabular}{|c|c|c|c|c|}
\hline$\$ 1$ of Aid as: & $\triangle \mathrm{SAE}$ & $\triangle$ SWL & $\triangle O E X P \star$ & $\triangle \mathrm{SREV}$ \\
\hline LSGRS & -.15 & -.34 & 1.20 & -.09 \\
\hline LSEA & .66 & .94 & .13 & .17 \\
\hline LSWA & -.16 & .28 & 1.04 & -.01 \\
\hline OFA & -.21 & -.22 & 1.17 & -.12 \\
\hline CEM & 1.07 & .22 & 1.72 & 1.88 \\
\hline m & -.33 & 1.35 & .79 & -.02 \\
\hline By-Pass & .49 & .98 & .79 & 1.67 \\
\hline INC & .008 & .031 & .021 & .041 \\
\hline
\end{tabular}

* In all cases, $\triangle O E X P$ is calculated as the residual change necessary to balance the state budget after equilibrium adjustments in SAE, SWL, and SREV. 
SWL, and the implied elasticities of spending and revenue with respect to e never exceed .01 . What small budget effects result from an increase in the effort rate favor $S A E$ and $O E X P$.

(2) Categorical, Lump-Sum Aid. There are three categorical, lump-sum grants considered here, one for each expenditure category -- LSEA (education), LSWA (welfare), and OFA (OEXP). These grants are nominally restricted to be spent only on the specified programs. However, states can comply with the terms of the grant by spending the aid dollar as specified but then cutting back on their own expenditures on closely related state-funded projects. Some, or perhaps even all, of the categorical aid dollars can thereby be "released" for allocations elsewhere in the budget. This is in fact what happens with LSWA and LSEA assistance. A dollar of Federal lump-sum welfare aid (LSWA) increases state welfare spending by only $\$ .076$, of which the state pays only the fraction $(1-m \theta)$ or $\$ .03(=.4 \times .076)$. LSWA also lowers state education aid spending by $\$ .20$. This decline in SAE is not surprising since many of targeted programs in LSWA assistance are for low-income, school-age children. The total "released" dollars for each dollar of Federal LSWA is $\$ 1.17, \$ .97$ from welfare and $\$ .20$ from education. However, only $\$ .12$ of these released dollars are allocated to revenue relief; aSREV/ JLSWA $=-.12$. OEXP receives the remaining $\$ 1.05$.

LSEA is somewhat more productive when it comes to keeping Federal aid dollars within the target category, perhaps because a major component of LSEA is Title I school assistance for low-income children and this program has been closely monitored by Federal auditors. Approximately, $\$ .43$ of each LSEA 
dollar remains in $\mathrm{SAE} ;$ aSAE/ $2 \mathrm{LSEA}=.43 .^{29}$ Welfare spending rises by $\$ .23$ as well, perhaps because of a regulatory spillover onto child welfare programs. Not all of the LSEA dollars remain in human services, however. Each dollar of aid Increases education plus the state share of welfare spending by $\$ .52$ $(=.43+.23(1-\mathrm{m} \theta)=.43+(.23 \times .4))$ so $\$ .48$ is allocated to tax rellef and OEXP. The coefficient of LSEA on SREV suggests tax relief receives $\$ .39$ per dollar of aid, leaving $\$ .09$ for OEXP.

Other Federal ald (OFA) helps only OEXP. A dollar of OFA leads to a $\$ .16$. reduction in SAE, a $\$ .057$ reduction in SWL with a state share of $\$ .025$ $(=.057(1-m \theta)=.057 \times .4)$ and a $\$ .005$ rise in SREV; overall OEXP rises by $\$ 1.19(=1+.16+.025+.005)$.

(3) Categorical, Closed-ended Matching Aid. A prominent form of categorical Federal assistance is to require the state to "match" a fixed amount of Federal aid with some corresponding number of state dollars at a given mark-up -- e.g., $\$ 2$ of state money for each dollar of Federal aid. (The fact that the amount of Federal aid is fixed distinguishes these programs as "closed-ended" matching grants.) The Federal hope is that these levered dollars will stay within the program area. However, in the case of education and welfare aid (school breakfast and lunch assistance and low-income commodity assistance) there is only partial retention; again OEXP captures the spillover. The average, required mark-up of Federal aid dollars can be estimated from the SREV equation as the increase in state revenues induced by a dollar increase in CEM aid: 2 SREV/ 2 CEM $=.61+.00035$ - INC. Evaluated at the mean income in our sample (INC $=\$ 2950 /$ capita) the implicit state match 
for the CEM program is 1.64. The rate of mark-up rises with state income as is in fact required by the Federal law for the programs in CEM. For the average income state, therefore, a dollar of Federal aid must be matched by $\$ 1.64$ of state money. Thus $\$ 2.64$ flows into the categorical program areas in education and welfare. Only $\$ 1.03$ remains, however, $\$ .98$ in education spending and $\$ .05$ in welfare assistance. OEXP captures the residual flow of $\$ 1.64(=2.64-.98-.05(1-\mathrm{m} \theta)=1.66-(.05 \times .4))$. It is clear that the Federal match requirement brings more dollars into the target programs, but it also provides state legislators with a reason to increase taxes and to reallocate all of that increase to their favored programs in OEXP.

(4) Open-ended Matching Aid. The most regulated of the Federal aid programs is an open-ended matching grant which operates as a tax-price subsidy. Aid is only recelved when dollars are spent on the targeted program, and further, additional state spending is rewarded with additional Federal aid. The net effect of such assistance is to lower the per unit costs to taxpayers of providing the aided service. If $m$ is the open-ended Federal matching rate and $\theta$ is the share of state spending covered by aid, then $(1-m \theta)$ is the share of expenditures which must be paid by taxpayers. The major open-ended matching grants now used by the Federal government are for the state provision of welfare spending on AFDC and Medicaid. For all states participating in the program, the rate $m$ varies from a low of .5 for the richer states (INC $>$ national average income) to a high of .78 for the poorest states. The share of total welfare spending in AFDC and Medicaid $(\theta)$ is $\simeq .8$ for states in our sample. We have estimated the effects of $(1-m \theta)$ on state 
spending and revenues. ${ }^{30}$ Calculated at the means, the implied tax price elasticities for $(1-m \theta)$ are +.22 for $\operatorname{SAE}$ (a positive cross-price effect), -.17 for SWL (a negative own price effect), -.08 for OEXP (a negative cross-price effect), and +.07 for SREV (implying a negative cross-price elasticity of -.001 for private income). Welfare and education are (loosely speaking) substitutes in the state budget, while welfare, private income, and other expenditures are complements. If states transfer more income to the poor, they apparently transfer more income to other income classes also. The transfers are facilitated by a reduction in the education budget and increased Federal aid. In fact, the dollar flows to the middle and upper income groups may exceed those to the poor. Again we do our calculations for the average state. A rise in the average state's effective matching rate (m $\theta)$ from .60 to .615 will bring in $\$ 1 /$ capita more in welfare matching aid. This additional dollar will initially be spent on the targeted activity increasing state welfare expenditures by $\$ .34$. The additional $\$ .34$ of sWL brings in an additional $\$ .21(=.615 \cdot .34)$ of aid. As $m$ increases, $(1-\mathrm{m} \theta)$ falls and SAE falls too -- by approximately $\$ .54$. SREV also falls by an estimated $\$ .63$. OEXP rises, however, by $\$ .78(\equiv \$ 1-\triangle \mathrm{SAE}-\Delta \mathrm{SWL}(1-.615)+\Delta \mathrm{SREV}=\$ 1+.54$ -.34(.385) - .63). Again, other expenditures and tax relief are the favored outlets for Federal assistance, even when that assistance is targeted to the poor.

This pattern of state spending which allocates new, marginal dollars towards OEXP is also observed in how states react to Federal assistance which by-passes the state and is paid to local governments and to households 
directly. Such Federal aid will still be available to state legislators if they are willing to tax back some or all of the aid through an increase in state revenues. For the earned income tax credit (EITC) and food stamps (FS) paid directly to low-income households, and for Federal impact school aid (IMPA) paid to school districts, this seems to be what happens. We do not observe a statistically significant tax-back effect with low income housing ald (LHA) paid to local governments. For a state with the average EITC grant (= $\$ 2.91 /$ capita), a dollar of EITC assistance triggers a $\$ .50$ increase in state revenues which is allocated entirely to school aid (\$.47) and state welfare $(\$ .25$, of which the state pays $.25(1-m \theta)=.25 \times .4=\$ .10)$; here OEXP seems to jose on average $(-\$ .07)$. There is a similar tendency to tax back food stamp assistance. A dollar of food stamp aid to the household sector is offset in part by a $\$ .69$ increase in SREV which is spent on SAE $(\$ .34)$, on welfare $(\$ .12$, which requires $\$ .05$ from the state $=.12(1-\mathrm{m} \theta)=$ $.12 \times .4)$ and on OEXP $(\$ .30)$. School impact ald (IMPA) has the most pronounced effect on SREV -- $\$ 3.22$ for each dollar of federal-to-local school aid(!) -- and OEXP is a main beneficiary receiving $\$ 1.68$ after the SAE ( $\$ 1.16)$ and SWL ( $\$ .95$, with a state share $=.95 \times .4=.38)$ allocations. We have difficulty rationalizing the size of this effect of IMPA on SREV, however, particularly since our earlier work (Craig-Inman, 1982) for a shorter, but largely overlapping, sample period (1965-1977) found a large, negative effect of this aid on state taxes. We can only suggest a cautious use of the IMPA results. Finally, a dollar of Federal-to-local housing aid (LHA) has a modest positive, but not statistically significant, effect on SREV (\$.12) and 
depressing, but not significant, effects on $\operatorname{SAE}(-\$ .76)$ and SWL $(-\$ .32)$; if we accept these coefficients as measuring average effects, OEXP spending rises by $\$ 1.01$ for each dollar of LHA. Over all four by-pass aid programs considered here, a dollar of increased Federal aid to each program will stimulate a full tax-back of $\$ 4.53$, allocated $\$ 1.21$ to SAE, $\$ 1.00$ to SWL (of which the state pays $\$ .40$ due to $\mathrm{m} \theta$ aid), and $\$ 2.92$ to OEXP.

Increases in average state income (INC) stimulate a larger state budget, with low income assistance and "other expenditures" as the favored outlets. A doliar of INC increases SREV by $\$ .025$, which induces a $\$ .003$ rise in SAE, a $\$ .008$ rise in SWL (though the state share is only .0032), and a .019 rise in OEXP. The private income elasticity of demand for state education assistance is .13, , for state welfare assistance is .45 , for "other expenditures" is .26, and for state revenues .32. Our results also confirm the presence of a flypaper effect on state budgets. Most all of private income stays in the private sector; most all public aid dollars stay in the public sector.

The non-aid variables included in the analysis to reflect across-stateand-time changes in voter coalition bliss points and political structure reveal no major surprises. The three tax price variables -- OLD, PRIV, and FHH -- are either insignificant or as in the case of FHH in the SWL equation, significant and of the correct sign. The coefficients for the five "taste" variables -- HS, KIDS, METRO, UE, MAN -- reveal a revenue-spending pattern which favors OEXP and tax relief over human services (SAE, SWL) in those states with a large number of existing manufacturing jobs, which are heavily urbanized, with relatively high rates of unemployment (though SWL does 
increase in response to UE), fewer children per famlly, and wore high school graduates. 31 These states tend to be the older, urbanized states of the east, south and mldwest. One plausible explanation for this observed spending pattern is that these are also the states under intense fiscal pressure as they struggle to retain mobile capital and jobs. What business wants is tax relief and "other expenditures", not school aid and welfare, and the states seem to be responsive.

The political structure variables -- R, $P$, WHT, and the individual state constant terms -- show state fiscal policy is not responsive to the income class divisions as measured here, once we have accounted for the effects of average income. While income class seems unimportant, racial divisions are not. As the percent of the state's population becomes more white, fewer dollars are allocated to $\mathrm{SAE}$ and to SWL, the human service portion of the state budget. Quantitatively, the effects of major swings in the racial composition of the state are important; states one standard deviation below the mean percent white spend approximately $\$ 24 /$ capita more on human services and $\$ 13 /$ capita less on OEXP than states one standard deviation above the mean percent white. $^{32}$ The individual state constant terms meant to capture the idiosyncratic nature of state political structures are reported in Appendix $B$. As we emphasized in section II, state budgetary politics is a dynamic process. Our results illustrate the importance of these dynamics. First, from the coefficient on TIME we observe a continual upward drift in real state spending and revenue over time, favoring SAE $(\$ 6.64 /$ capita per year) and OEXP $(\$ 3.20 /$ capita per year $=\Delta \mathrm{SREV}-\Delta \mathrm{SAE}-\Delta \mathrm{SWL}(1-\mathrm{m} \theta)=10.21-6.64-$ 
$.92(.4))$. Second1y, our theory of budgetary polltics predicts an important role for the level of last year's services in this year's budgeting (the status quo), and our empirical analysis confirms this prediction. We have modeled the dynamics of the political process by including lagged service levels for education $\left(P_{-1}\right.$, WAG -1 , and $\operatorname{NPEXP}_{-1}$ ) and welfare $\left(\mathrm{SWL}_{-1}\right)$ in each of the three estimated budget equations; the lagged service variables are always statistically significant as a set. ${ }^{33}$ Further, the implied dynamic adjustment process has important implications for the final disbursement of fiscal resources. While the feedback effects of lagged school services on state spending and taxes are modest with most effects of a fiscal change felt in the first year, lagged welfare spending has a quantitatively important impact -- particularly on SWL, SREV, and OEXP -- which takes from four to six years to be fully felt. ${ }^{34}$ There is an inertia in state welfare budgeting as legislators seem reluctant to expand or cut welfare spending too quickly, perhaps concerned about the reaction of neighboring states (see Gramlich, 1982). Table 2 summarizes our estimates of the equilibrium effects of changes in each of the exogenous fiscal variables in our model allowing for the dynamic adjustments to the budget through lagged education and welfare services. 35 The table reports the equilibrium effects of an additional $\$ 1$ of Federal assistance paid either directly to the states or as "by-pass" assistance to households and local governments. The calculation for Federal by-pass aid allocates $\$ .25$ to each of the four by-pass programs in our study (EITC, FS, LHA and IMPA). We also show the equilibrium allocation of an additional dollar of state private income. Qualitatively, the equilibrium effects of aid and income parallel the impact effects described above: 
OEXP is generally favored, but (2) the more regulated is Federal aid, the more likely it is to remain within the target expenditure category. Quantitatively, the equilibrium effects of aid on the human resource portion of the state budget exceed the impact effects of aid, primarily because of lagged adjustments to welfare spending. Positive "shocks" to the human resource budget (via $\mathrm{m}$, CEM, LSEA, LSWA, and INC) increase SAE and SWL over time while negative shocks (via LSGRS and OFA) decrease SAE and SWL over time. OEXP is largely unaffected; it is SREV which adjusts to the changes in SAE and S SWLL.

Overall, both the impact and the dynamic equilibrium analyses of Federal assistance to the state-local sector reveal the same essential pattern to desired state spending: Federal dollars which flow into the state via grants-in-aid are allocated disproportionally towards OEXP and away from the human services components -- SAE and SWL -- of the state budget. It is important to know why. This analysis cannot answer that question -structural, not reduced form, models are needed -- but we will offer one hypothesis which, on its face, we find persuasive. Like their counterparts in Washington, state legislators are rewarded with re-election when they deliver publicly funded programs to their constituents and when those additional public dollars can be explicitly linked to the efforts of the elected official. $^{36}$ Public expenditures which are most conducive to district-bydistrict, constituent-by-constituent allocations are those outlays which can be allocated by legislative or bureaucratic choice, not formula. Both welfare assistance and school aid are disbursed according to pre-established 
formulas. 37 The real battles for state dollars are fought in the non-formula expenditures -- that is, in OEXP. Thus the more money to OEXP the better, for it makes all legislators better of.$^{38}$ The major state services provided by OEXP dollars include state highway maintenance (potholes and jobs), state hospitals and medical centers (health care and jobs), universities (educational opportunity and jobs), parks (recreation and jobs), and state bureaucracies (services and jobs). Each of these programs permits discretion in dollar allocations. From these OEXP programs, alternative omnibus spending bills can be fashioned to insure majority approval of the state budget. OEXP is the grease or "pork" which keeps the wheels of state politics in motion. In such a world, it is not surprising that Federal aid dollars are re-channeled whenever possible into "other expenditures".

Nor is it surprising that those interested in reducing the size of government should wish to reduce and/or restructure the Federal aid system. President Reagan's "new federalism" reforms can be viewed as one attempt to curtail the flow of Federal aid dollars into state treasuries. The likely impact of the Reagan reforms on state budgets is described in Section $V$. The President will not be disappointed with the results.

\section{The Budgetary Effects of the New Federalism}

President Reagan's new federalism is a three step reform package whose primary intention -- Washington rhetoric aside -- is to reduce Federal and state-local government spending. Step (1) of the reform is to turn the AFDC and food stamp programs over to the states for financing and administration. 
In step (2) the Federal government will assume full responsibility for Medicald. Step (3) gives the state financial responsibility for sixty-one domestic aid programs in exchange for a lump-sum transfer per capita from a newly established trust fund, with trust fund payments reduced gradually unt11, by 1992, no further Federal lump-sum aid will be paid to the states. Table 3 summarizes the predicted equilibrium effects of these reforms on the allocation of state budgets to SAE, SWL, OEXP, and SREV.

The baseline for our simulation is the "average" in each budget category for our sample states in 1980; see Table 3. This average pre-reform budget for 1980 is then adjusted by the equilibrlum budgetary responses to changes in Federal grants-in-aid for each of two major components of the new federalism reform: the welfare exchange of AFDC and food stamps for Medicaid and the exchange of trust fund aid for 61 categorical programs. First, the simulations assume each component of the reform is done separately -- the columns labelled "welfare exchange" and "t cust fund exchange" in Table 3 -and then simulations are performed for the entire new federalism package with full trust fund aid (the column labelled "new federalism, 1988") and then without trust fund ald (labelled "new federallsm, 1992+"). For each simulation, we assume that (1) the effects of requiring state responsibility is equivalent to setting Federal aid equal to zero for the affected programs, (2) trust fund aid is equivalent to a lump-sum grant-in-aid, and (3) the Federal assumption of Medicald payments will induce state budget responses equivalent to those now observed for a similar existing Federal-to-poorhousehold aid program, food stamps. We also assume the earned income tax credit (EITC) will be unaffected by reform. 
Table 3

The Fiscal Fffects of the New Federalism*

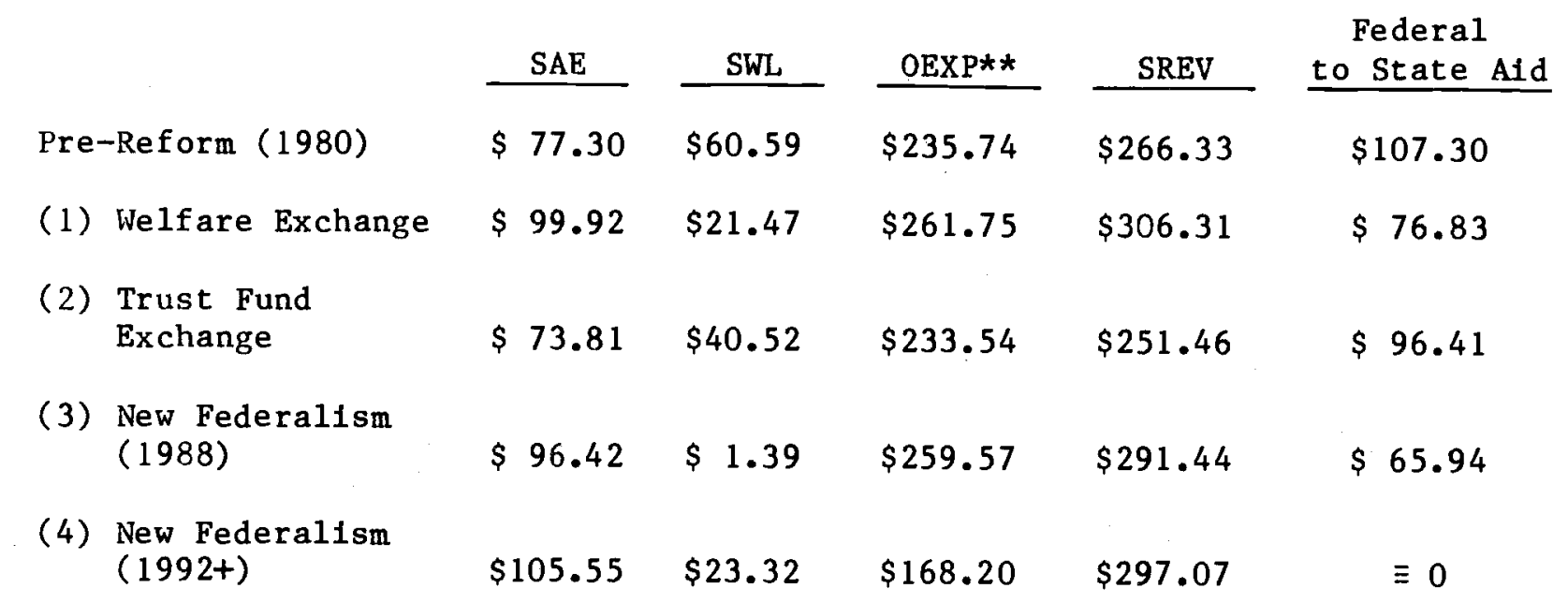

* All dollar figures are in real 1966 dollars per capita.

** In all simulations, OEXP is calculated as the residual category to balance the state budget. 
The transfer of food stamp aid and AFDC to the states and of Medicaid to the Federal level is functionally equivalent to setting the welfare matching rate (m) to zero, food stamp aid (FS) to zero, and establishing Medicaid assistance as a Federal-to-household by-pass ald program. The combined effects of these reforms are dominated by the change in the welfare matching rate from $m=.6$ to $m=0$. Equilibrium welfare spending falls by $65 \%$. State own revenues rise somewhat to offset the fall in Federal-to-state aid; these dollars along with the state dollars released from the welfare budget are allocated to education aid and other state expenditures. The exchange of trust-fund aid for categorical aid has a somewhat different pattern of effects, and favors tax relief. State assumption of Federal categorical aid implies all Federal-to-state aid (LSEA, CEM, LSWA, OFA) and all Federa1-tolocal aid (IMPA, LHA) in our model now receive zero funding. In their place, states receive a lump-sum grant from the Federal trust fund approximately equal to the value of the lost categorical aid. 40 Under this component of the new federalism package, state education and welfare spending fall, other expenditures remain the same, and state revenues and Federal aid decline. Again, we observe that once the categorical "strings" of Federal human resource aid are untied, dollars leave this portion of the state budget; in this case they go to state tax relief. Reagan's new federalism package combines the welfare exchange and the trust fund exchange. The policies' joint effects are not additive, however, because of the interaction of aid and spending levels in the equilibrium model. When full trust-fund aid is paid to the states (the new federalism to 1988), SAE and OEXP are the clear net 
gainers, while state taxes rise and state welfare falls to almost nothing. The welfare exchange plus the strong negative effect of LSGRS on state welfare spending (see Tables 1 and 2) are responsible for this large fall in SWL. When Federal trust fund aid is removed in 1992, we observe an increase in state own revenues, SAE and SWL, and a sizeable fall in OEXP.

While the exact dollar predictions in Table 3 must be interpreted with care, we feel the overall impression left by these simulations is valid. In the end, the new federalism reforms will reduce welfare spending, increase education spending, reduce state expenditures on "other" goods and services, and increase state revenues. The combined size of Federal-state-1ocal government will also decline. Though state (and possibly local) government revenues increase (by about $\$ 30 /$ capita in Table 3), Federal spending is reduced by the amount of saved Federal aid (\$107.30/capita) less any increases in Federal Medicaid spending $(\simeq \$ 17 /$ capita, if 1980 average state Medicaid spending is maintained).

On balance, it appears the new federalism of President Reagan will achieve its objectives. Government, and particularly pork-barrel government, is smaller. The possible price we pay is less public assistance for low income households.

VI. A Concluding Comment

The U.S. federalist public economy has evolved to the point where today the Federal government is the primary provider of public dollars and the state-local sector is the primary provider of public services. There are good 
reasons to doubt the efficiency of such a fiscal structure, particularly if the wedge between the revenue and spending responsibility is large. Grantsin-aid is the source of that wedge. Efforts to reform our current system of grants-in-aid requires a careful understanding of the effects of aid on state and local fiscal choice: first, to answer the question of whether Federal aid is a cause of inefficiency, and if so, to then fashion a reform policy to improve resource allocations. ${ }^{42}$ The formal analysis of state-local fiscal choice must recognize the fact that state and local governments are political institutions, however, and that the grants-in-aid system is an integral part of that institutional structure. This first analysis confirms the importance of grants as a structural determinant of state budgetary choice. The task before us now is to reveal more fully just how this structure works and to exploit that knowledge to improve public sector resource allocations. 
Craig and Inman

\section{Footnotes}

* University of Houston and University of Pennsylvania and the NRFR, respectively. The authors would like to thank the NBER for partial funding for this research, the Center for Public Policy and a Research Initiation Grant at the University of Houston which supported a portion of Craig's research, and the NSF (under grant SES-8112001) which supported a portion of Inman's research. The comments of Helen Ladd, Ron Fisher and the participants at the Bureau's conference on state and local finance (June 15-16, 1984) pushed us to significantly revise and extend our initial research. We hope this new product does justice to their excellent comments.

1. For a description of the historical evolution of our federalist public economy, see Scheiber (1966).

2. The Federal share of all non-defense, government spending has grown from $28.5 \%$ in 1902 to $48.8 \%$ by 1983 . The source of this growth has been the increase in federally funded transfer programs to families and to governments. The state-local sector has always been the main producer of public services. The state-1ocal sector's share of non-transfer, non-defense government spending has grown from $71 \%$ in 1902 to $84.6 \%$ by 1983. Financial control has become more centralized; production has become less centralized. Bridging the widening gap between the financing and provision of public services are grants-in-aids; see Inman (1985). 
3. See Inman (1985).

4. See Inman (1985) for some thoughts on this issue based upon the political history of our existing fiscal system.

5. The level of free $g(=\hat{g})$ made available by lump-sum aid is $(z / n) / c(1-m)$. As $z$ dollars of aid buys $z / c(1-m)$ units of $x$ and $x$ provides $x / n$ units of $g, \hat{g}=(x / n)=(z / n) / c(1-m)$. The assumption in this calculation is that expenditures from $z$ aid can be "leveraged" further by matching aid.

6. See the work of Bergstrom and Goodman (1973) and Inman (1978).

7. See Inman (1979) for a review of the U.S. experience and Jackman and Papadachi (1981) and Pommerehne (1978) for examples of applications of the median voter model to fiscal choice in European communities.

8. The theory predicts that the effects of $I$ and $(z / n)$ work only through full fiscal income, $\hat{I}$. While a dollar more of $I$ increases $\hat{I}$ by one dollar, a dollar more of $(z / n)$ increases $\hat{I}$ by $\pi(b / B)$, which generally is not equal to 1 . If $\pi(b / B)<1$, a dollar of private income (I) should have a greater stimulative effect on the demand for $g$ than a dollar of lump-sum aid per capita $(z / n)$. If $\pi(b / B) \equiv 1$, then I and $(z / n)$ should have equal effects on $\mathrm{g}$.

9. Two alternative explanations have been offered for the flypaper effect. Moffitt (1984) argues that the flypaper effect may be due to a misspecification of the resident's budget constraint by failing to allow for nonlinearities of the constraint, e.g., the kink in the constraint at point $C$ in Figure 1. Moffitt explicitly allows for such kinks and bends 
in the resident's budget constraint when estimating a budgetary model for state welfare programs and finds that after such a correction the effects of the lump-sum component of such aid cannot be statistically distinguished from the effects of residential income, i.e., there is no flypaper effect. While such nonlinearities are important in welfare aid, and Moffitt is clearly correct to allow for these, most other Federal and state aid programs for which the flypaper effect has been found do not involve nonlinear budget constraints over the relevant range of local fiscal choice. For most programs, full fiscal income, $\hat{I}$, or its components I and $(z / n)$, are the correct independent variables.

Hamilton (1983) has also argued that the flypaper effect is due to an error in specification, now of the technology of local service provision. Resident income plays two roles, not one. Income defines the resident's available resources, but income also is a determinant (or a very good proxy for the true determinants) of local service production. It is generally less expensive to provide a given level of services, $g$, in rich towns than in poor towns. Local service costs (c) depend on I; as I increases, c declines. Resident income therefore plays two roles: (1) as a part of full fiscal income $(\hat{I})$ and (2) as a part of the production function and local service costs (c). If income increases and c falls, then the local tax price falls, and we demand more g (Hamilton's output effect). But the fall in $c$ means it is cheaper to produce any $g$ and thus we need spend less on public inputs (Hamilton's substitution effect). If the substitution effect dominates the output effect, then 
the total effect of I through the production relationship on public input use will be negative. Thus while resident income and lump-sum aid may have nearly identical effects on local spending because of their effects on full fiscal income $(\hat{I})$, resident income may have an additional, possibly negative effect because of its role in the production of local services. The effect of $I$ on local spending will be less than the effect of $(z / n)$ on local spending. Hamilton tests his model for plausible parameter values and finds that it accounts for about half of the observed filypaper effects. But "the parameter values required to explain the entire flypaper effect appear to be implausible" (Hamilton, 1983, p. 355). Hamilton's hypothesis, while interesting, cannot really save the resident utility maximization explanation of state-local fiscal choice. Something more is needed.

10. See Niskanen (1975) for the motivation behind this objective of politician-bureaucrat behavior.

11. See Filimon, Romer, and Rosenthal (1982) or Inman (1981) for alternative model specifications.

12. This particular positioning of each coalition's preferred allocations is only illustrative; the analysis which follows holds equally well for alternative combinations of preferences. Implicit in this particular configuration is the view that education and a concern for the less fortunate are both normal goods with respect to income, and that all income classes also have a social insurance motive for supporting low income assistance programs. Even Boeing engineers have need for food 
stamps every once in awhile. The social insurance motive dominates the altruism motive for the poor leading to a high welfare demand for this coalition, while the altruim motive is relatively strong for the upper income groups inducing a relatively high demand for welfare by this coalition. The blue collar middle class, motivated by neither altruism nor a need for public income insurance, has a low demand for welfare.

13. The relative voting strength of the three coalitions need not be equal for the analysis which follows. All that really is required is that no one coalition hold an absolute majority by itself, for then the analysis reduces to a study of a dictator and the fiscal model behind equation (1) will be sufficient.

14. An example of such a jurisdictional structure are special districts which can decide allocations on only one policy dimension, taking the allocation of other special districts as given. In our example, a school district decides on $g_{1}$ and a welfare district sets $g_{2}$. We will not consider the interaction between special districts which sets the joint allocation of $g_{1}$ and $g_{2}$, but see Shepsle (1979) or Inman (1984).

15. A fully open amendment process where any proposal can be considered would undo the committee and jurisdictional structures and return the decision process to the majority rule only case and its prediction of no stable equilibrium.

16. Points off the contract line will always be rejected in favor of points on the contract line by the R-P coalition, so we need consider only points on the line. 
17. If the status quo point is not fixed then a new equilibrium point will emerge. Specifically, if the budgeting process is a dynamic one in which the last period's budget is the next period's status quo, then it is possible to show that the group which controls the agenda can move the budget allocation arbitrarily close to its ideal point over time. For example, if we repeat the analysis above using $\varepsilon^{\star *}$ as the status quo, the new, next period allocation will be on the R-P contract line closer to the ideal point, $R$, than $\varepsilon * \star$.

18. See also Denzau and Parks (1979) who provide a general treatment of the problem of specifying voter preferences for policy outcomes from a basic preference structure over primary goods and services.

19. The analysis here assumes the coalitions in conflict are three consumer groups who have demands for the public services. While this is reasonable, the model can be extended to allow industry groups or even public employees to have a direct say in the final allocations. To formally include such groups in the analysis we must define their preferences for outcomes. Niskanen (1975), Inman (1981), and Courant, Gramlich, and Rubinfeld (1979) offer such models for public employees, while Stigler (1971) and Peltzman (1976) have specified profit maximization models of firm or industry preferences for pub1ic service allocations.

20. The Romer-Rosenthal analysis can be seen as a special case of this more general structure. Specifically, Romer-Rosenthal consider the one jurisdiction case in which the high-spending coalition is the 
agenda-setter. In terms of our analysis, this corresponds to Figure 3 with the rich coalition as the agenda-setter. The allocation of $\varepsilon^{*}$ results which exceeds the allocation which would have emerged from a median voter model (point $\mu$ ). Point $B$, our status quo, corresponds to Romer-Rosenthal's so-called "reversion level".

21. See Reischauer (1975) for estimates of e.

22. Our original definition of the tax price in Section II above assumed a11 taxpayers used the public service. A simple re-calculation of $p$ will show that if $n$ people pay taxes (so $B$ - $n$ is still the aggregate tax base) but only $u$ people use the public service ( 0 o $g=x / u$ ), then the definition of $p$ becomes $\pi(b / B)(u / n)(1-m) c$, where the new term $(u / n)$ is the percent of population who use the public service. As PRIV rises, $(u / n)$ falls and the tax price for education falls, while if OLD or FHH rises, $(u / n)$ rises and the tax price for welfare rises.

23. Aid programs explicitly for the elderly, such as Social Security and Medicare, have been excluded. Only means tested programs are included in order to confine the analysis to political choice over a common set of goals. Similarly, unemployment and training programs such as CETA have been excluded because they are motivated by a different set of coalition determinants.

24. Since our continuous aid, income, and demographic variables are likely to capture most systematic differences across states in coalitions' preferences -- the bliss points -- we are reasonably confident that our state dummy variables will capture the systematic effects of state 
political and institutional differences on fiscal allocations. Exploring exactly what these differences might be is the task for later research.

25. The cost-of-living index used in this study is an update of an Index we created in our previous study of Federal-state-local finance of education. See Craig-Inman (1982, p. 545).

26. See Zellner (1962) and Hausman (1978).

27. For specialists in state-local finance, our reduced-form equations will appear (as they are) to be "old wine in a new bottle". The variables are familiar ones used in most previous budgetary models. We have given them a potentially new interpretation, however, an interpretation which we find more compelling for reasons outlined in Section II above.

One note of caution must be sounded before presenting our results. Like all reduced form budget studies, we must assume that a change in a policy variable -- e.g., Federal aid -- does not alter the basic political structure which defines spending or revenues. For example, less Federal aid for the poor does not lead to more or less political Influence for the poor in state budgeting. If so, the reduced form model will be misspecified. The assumption of no structural change is probably valid for small adjustments in Federal assistance, or for the first few years following large changes in assistance. Our results must be interpreted with this caveat in mind.

28. All marginal effects are calculated at the means. The decision to use a logarithmic specification for LSGRS reflects the fact such aid has generally been found to have nonlinear effects on spending and revenues; 
see Inman (1979).

29. LSEA is comparable to "pass-through education aid" of our previous paper (Craig-Inman, 1982). Comparing the results here to those of our earlier paper shows this aid has a smaller effect on SAE than previously estimated. Additional years and a more complete specification in this study lead us to favor these results.

30. The estimation of the effects of matching aid is problematic. The voters' budget constraints need not be straight lines, but can have complicated "kinks" depending on whether the state enrolls under one aid formula or another. The AFDC formula is a subtle combination of open-ended and close-ended grants and requires a rather involved nonlinear estimation procedure; see Moffitt (1984). The Medicaid formula, however, does not involve such "kinks" and by 1974 most states were using this simpler aid formula. We have chosen to restrict our analysis to the sample of states which use the Medicald formula, and to then address the problem of selection bias such a restricted sample may impose upon our results. We have adopted the procedure of olsen (1980) for the correction of selection bias. In the SAE and SWL equations the variable to correct for selection bias was not significant, implying no bias. The variable was significant in the SREV equation, though the degree of bias in coefficients was small. We could not apply the procedure to all years in our original sample, however, because of data limitations. We have chosen, therefore, to present the uncorrected results in Table 1, under the (largely substantiated) assumption that the 
bias will be small.

31. OEXP will rise if the decline in SAE and SWL dominate any decline in SREV.

32. The mean percent white for our sample 1s 90.07 (s.e. = 8.83). The change in percent white from a low state to a high state is 17.66 percent inducing a change in SAE of $-\$ 16.42$, a change in SWL of $-\$ 7.24$, and a change in SREV of $-\$ 6.53$. The resulting change in OEXP from the state budget identity is $\$ 12.79(=\Delta \mathrm{SREV}-\Delta \mathrm{SAE}-(1-\mathrm{m} \theta) \Delta \mathrm{SWL})$.

33. The fact that education services are provided by local school districts leads us to use local school personnel per enrollee (PER), local school payroll per employee (WAG), and non-personnel expenditures per enrollee (NPER) as our measures of education services. State welfare services as social insurance or as a redistributive public good are assumed to be available to all residents equally, so lagged SWL is used to measure welfare service levels.

An $F$ test as to the joint significance of lagged PER, WAG, NPEXP, and SWL in the SAE, SWL and SREV equations leads us to reject the null hypothesis of no significance in each case. The value of the respective F statistics are 6.33 (for SAE), 160 (for SWL) and 17.54 (for SREV).

34. We have calculated the dynamic structure for changes in state education aid using a local fiscal model previously estimated in Craig-Inman (1982) which specifies the effects of SAE on PER, WAG, and NPEXP. A change in $\mathrm{SAE}_{-1}$ changes $P E R_{-1}$, WAG ${ }_{-1}$, and $\mathrm{NPEXP}_{-1}$ which in turn influence $\mathrm{SAE}$, SWL, and SREV today. Tracing through the dynamic influences of last year's 
SAE on this year's SAE, SWL, and SREV, we can estimate the influence of one dollar of $\mathrm{SAE}_{-1}$ as .059 on $\mathrm{SAE}$, as .007 on $\mathrm{SWL}$, and .134 on SREV. Thus the dynamic effects of last year's state education aid on this year's state budget are small. These results should be contrasted to the effect of a dollar of $\operatorname{SWL}_{-1}$ on $\operatorname{SAE}(.17)$, SWL (.75) and $\operatorname{SREV}(.47)$. These large marginal effects will take several years before adjustment is complete.

35. The equilibrium effects of exogenous aid changes on SAE, SWL, and SREV were estimated by solving this three equation dynamic model:

$$
\begin{aligned}
& \mathrm{SAE}=\phi \mathrm{X}+.17 \mathrm{SWL}_{-1}+.059 \mathrm{SAE}_{-1}, \\
& \mathrm{SWL}=B \mathrm{X}+.75 \mathrm{SWL}_{-1}+.007 \mathrm{SAE}_{-1}, \text { and } \\
& \mathrm{SREV}=\theta \mathrm{X}+.47 \mathrm{SWL}_{-1}+.134 \mathrm{SAE}_{-1},
\end{aligned}
$$

where the impact coefficients $\phi, B, \theta$ for the exogenous aid variable (X) and the coefficients on $S_{-1}$ are as reported in Table 1 , and the coefficients on $\mathrm{SAE}_{-1}$ are as reported in footnote 34 above. The dynamic equilibrium of ald changes on OEXP were calculated from the state budget identity. The interpretation of these dynamic results is subject to the caveats of footnote 27 above.

36. See for example Fiorina (1977).

37. How these formulas are chosen is itself an important question which we hope to address in future research.

38. The presumption here is that there is no effective tax relief coalition within the state which can divert dollars from OEXP to tax relief on a 
regular basis. The sporadic success of the state tax 11mitation movements seems to be evidence on this point.

39. Before discussing the simulation results we must emphasize that the numbers in Table 3, which look precise, are not. In calculating equilibrium effects we used all estimated aid coefficients in our model, many of which are statistically insignificant (see Table 1). Further, the policy changes we are simulating can hardly be considered "sma11" changes which fall within the range of current sample variation. Whether the observed fiscal behavior holds outside the sample is an unanswered question. At best Table 3 provides only a first impression of what may happen under the new federalism.

40. The new federalism reform agreed to pay approximately $90 \%$ of the 1ost categorical aid, which was about $\$ 73 /$ capita. Thus lump-sum aid from the trust fund will be $\$ 65.94$.

41. It is also possible the form of the remaining assistance will change. See Craig and Kohlhase (1985).

42. The Reagan Administration's reform is only one alternative. See Gramlich (1985) for another proposal of merit. 


\section{References}

Arrow, K. J. (1963), Social Choice and Individual Values, 2nd ed., John Wiley, New York.

Baltagi, B. H. (1981), "Pooling: An Experimental Study of Alternative Testing and Estimation Procedures in a Two-Way Error Component Model," Journal of Econometrics, 17, pp. 21-49.

Bergstrom, T. C. and R. P. Goodman (1973), "Private Demands for Public Goods," American Economic Review, 63, pp. 280-296.

Bowen, H. (1943), "The Interpretation of Voting in the Allocation of Economic Resources," Quarterly Journal of Economics, Vol. 58, pp. 27-48.

Courant, P. N., E. M. Gramlich, and D. L. Rubinfeld (1979), "Public Employee Market Power and the Level of Government Spending," American Economic Review, 69, pp. 806-817.

Craig, S. G. and R. P. Inman (1982), "Federal Aid and Public Education: An Empirical Look at the New Fiscal Federalism," Review of Economics and Statistics, 64, pp. 541-552. and J. Kohlhase (1985), "Why There Is Not a Unifled Welfare System: Fiscal Federalism from an Agency Approach," in Quigley, J. (ed.), Perspectives on Local Public Finance and Public Policy, II, JAI Press, forthcoming.

Denzau, A. T. and R. P. Parks (1979), "Deriving Public Sector Preferences," Journal of Public Economics, 11, pp. 335-352.

Filimon, R., T. Romer, and H. Rosenthal (1982), "Asymmetric Information and 
Agenda Control: The Basis of Monopoly Power in Public Spending," Journal of Public Economics, Vol. 17, pp. 51-70.

Fiorina, M. (1977), Congress: Keystone of the Washington Establishment, Yale University Press, New Haven, CT. Gramlich, E. (1982), "An Econometric Examination of the New Federalism," Brookings Papers on Economic Activity, 2, pp. 327-360. (1985), "Reforming U.S. Federalism Arrangements," in Quigley, J. and D. Rubinfeld (ed.), Urban America and the Reagan Budget, University of California Press, Berkeley, forthcoming. Hamilton, B. (1983), "The Flypaper Effect and Other Anomalies," Journal of Public Economics, Vo1. 22, pp. 347-362.

Hausman, J. A. (1978), "Specification Tests in Econometrics," Econometrica, 46, pp. 1251-1271.

Inman, R. P. (1978), "Testing Political Economy's 'As If' Proposition: Is the Median Income Voter Really Decisive?" Public Choice, 33, pp. 45-65. (1979), "The Fiscal Performance of Local Governments: An Interpretative Review," in Mieszkowski and Straszheim (eds.), Current Issues in Urban Economics, John Hopkins University Press, Baltimore, pp. 270-321.

(1981), "Wages, Pensions and Employment in the Local Public Sector," in Mieszkowski and Peterson (eds.), Public Sector Labor Markets, Urban Institute Press, Washington, D.C., pp. 11-57. (1984), "Markets, Governments and the 'New' Political Economy," in A. Auerbach and M. S. Feldstein (eds.), Handbook of Public Economics, 
Vol. II, North-Holland, Amsterdam, forthcoming.

(1985), "Fiscal Allocations in a Federalist Economy: Understanding

the New Federalism," in Quigley, J. and D. Rubinfeld (eds.), Urban

America and the Reagan Budget, University of California Press, Berkeley,

forthcoming.

Jackman, R. and J. Papdachi (1981), "Local Authority Education Expenditure in

England and Wales," in M. J. Bownan (ed.), Collective Choice in

Education, Martinus Nijhoff Publishers, The Hague, pp. 47-62.

Kramer, G. H. (1973), "On a Class of Equilibrium Conditions for Majority

Rule," Econometrica, 41, pp. 285-297.

Moffitt, R. (1984), "The Effects of Grants-in-Aid on State and Local

Expenditures: The Case of AFDC," Journal of Public Economics, 23, pp. 279-306.

Niskanen, W. (1975), "Bureaucrats and Politicians," Journal of Law and

Economics, Vol. 18, pp. 617-643.

Olsen, R. J. (1980), "A Least Squares Correction for Selectivity Bias,"

Econometrica, 48, pp. 1815-1820.

Peltzman, S. (1976), "Toward a More General Theory of Regulation," Journal of Law and Economics, 19, pp. 211-240.

Plott, C. R. (1967), "A Notion of Equilibrium and Its Possibility under Majority Rule," American Economic Review, 57, pp. 787-806.

Pommerehne, W. W. (1978), "Institutional Approaches to Public Expenditures:

Empirical Evidence from Swiss Municipalities," Journal of Public

Economics, Vol. 9, pp. 255-280.

Reischauer, R. (1975), "General Revenue Sharing -- The Program's Incentives," 
in W. Oates (ed.), Financing the New Federalism, Johns Hopkins University Press, Baltimore, pp. 40-87.

Romer, T. and H. Rosenthal (1979), "Bureaucrats vs. Voters: On the Political Economy of Resource Allocation by Direct Democracy," Quarterly Journal of Economics, Vol. 93, pp. 562-587.

Scheiber, H. N. (1966), "The Condition of American Federalism: An Historian's View," Subcommittee on Intergovernmental Relations to the Committee on Government Operations, U.S. Senate, October 15, 1966.

Shepsle, K. (1979), "Institutional Arrangements and Equilibrium in Multidimensional Voting Models," American Journal of Political Science, Vol. 23, pp. 27-59.

Stigler, G. J. (1971), "The Theory of Economic Regulation," Bell Journal of Economics, 2, pp. 3-21.

Zellner, A. (1962), "An Efficient Method of Estimating Seemingly Unrelated Regressions and Tests for Aggregation Bias," Journal of the American Statistical Association, 57, pp. 348-368. 
Appendix A

Data Description

\begin{tabular}{l} 
Dependent \\
Variable \\
\hline
\end{tabular}

SAE

SWL

SREV

Independent

Variable

LSWA

LHA

FS

EITC

m

OFA
Federal-state lump sum welfare aid, equals

total Federal-state welfare aid minus AFDC,

Medicaid, and SSI after 1973, deflated, per

capita

Federal-local welfare ald, equals housing

aid, deflated, per capita

Food Stamps, deflated, per capita

6.53

5.94

Earned Income Tax Credit, deflated, per

1.44

1.74

capita

State share of Federal matching aid

.403

Other Federal Aid, excluding welfare,

39.44

16.97

education, highway, and general revenue

sharing aid, deflated, per capita 
Data Appendix (continued)

\begin{tabular}{|c|c|c|c|}
\hline $\begin{array}{l}\text { Independent } \\
\text { Variable }\end{array}$ & Definition & Mean & $\begin{array}{l}\text { Standard } \\
\text { Deviation }\end{array}$ \\
\hline LSGRS & $\begin{array}{l}\text { Lump sum component of general Federal-state } \\
\text { revenue sharing, deflated, per capita }\end{array}$ & 1.76 & 1.99 \\
\hline e & State effort index for revenue sharing & .03 & .03 \\
\hline INC & Per capita state income, deflated & 2950.49 & 436.34 \\
\hline LSEA & $\begin{array}{l}\text { Lump sum Federal-state education aid, } \\
\text { including vocational and handicapped aid, } \\
\text { and Title } I \text {, deflated, per capita }\end{array}$ & 5.82 & 2.66 \\
\hline CEM & $\begin{array}{l}\text { Closed-end matching Federal-state aid, } \\
\text { included school breakfast and lunch and } \\
\text { commodity distribution, deflated, per capita }\end{array}$ & 4.31 & 2.63 \\
\hline IMPA & $\begin{array}{l}\text { Impact Federal education aid to local } \\
\text { governments, deflated, per capita }\end{array}$ & 1.91 & 1.59 \\
\hline HS & Percentage which completed high school & .59 & .09 \\
\hline KIDS & Average number of children per household & 1.18 & .18 \\
\hline $\mathrm{POOR}(\mathrm{P})$ & Percentage below $\$ 5,000$ annual income & .14 & .075 \\
\hline OLD & Percentage 65 years old and over & .10 & .014 \\
\hline $\mathrm{RICH}(\mathrm{R})$ & Percentage above $\$ 25,000$ annual income & .03 & .018 \\
\hline METRO & Percentage which live in a metropolitan area & .55 & .26 \\
\hline UE & Percentage unemployed & 5.59 & 1.88 \\
\hline MAN & $\begin{array}{l}\text { Percentage of the population working in } \\
\text { manufacturing }\end{array}$ & .086 & .033 \\
\hline FHH & Percentage of families headed by a female & 9.52 & 2.40 \\
\hline WHT & Percentage white & 90.1 & 8.83 \\
\hline
\end{tabular}


Data Appendix (continued)

\begin{tabular}{|c|c|c|c|}
\hline $\begin{array}{l}\text { Independent } \\
\text { Variable }\end{array}$ & Definition & Mean & $\begin{array}{l}\text { Standard } \\
\text { Deviation }\end{array}$ \\
\hline PRIV & $\begin{array}{l}\text { Percentage of school aged children in } \\
\text { private school }\end{array}$ & .094 & .058 \\
\hline PER $_{-1}$ & $\begin{array}{l}\text { School personnel per enrollee lagged one } \\
\text { year }\end{array}$ & 11.31 & 1.58 \\
\hline WAG $_{-1}$ & $\begin{array}{l}\text { Wages per school personnel lagged one year, } \\
\text { deflated }\end{array}$ & 5966.78 & 795.66 \\
\hline NPEXP_- & $\begin{array}{l}\text { Non-personnel expenditures per capita } \\
\text { lagged one year, deflated }\end{array}$ & 60.69 & 29.82 \\
\hline$S W L_{-1}$ & $\begin{array}{l}\text { State welfare expenditure lagged one year, } \\
\text { deflated, per capita }\end{array}$ & 50.17 & 23.03 \\
\hline
\end{tabular}


Appendix B

State Dumny Variables ${ }^{a}$

\begin{tabular}{|c|c|c|}
\hline ARK & $\begin{array}{r}-34.48 * \\
(6.09)\end{array}$ & $\begin{array}{c}-.63 \\
(3.52)\end{array}$ \\
\hline $\mathrm{CA}$ & $\begin{array}{c}46.15 * \\
(16.26)\end{array}$ & $\begin{array}{c}8.68 \\
(9.40)\end{array}$ \\
\hline $\mathrm{CO}$ & $\begin{array}{c}29.89 \\
(18.72)\end{array}$ & $\begin{array}{c}-12.12 \\
(10.82)\end{array}$ \\
\hline $\mathrm{CT}$ & $\begin{array}{r}34.98 * \\
(14.04)\end{array}$ & $\begin{array}{l}10.69 \\
(8.11)\end{array}$ \\
\hline $\mathrm{DE}$ & $\begin{array}{r}57.98 * \\
(13.15)\end{array}$ & $\begin{array}{c}1.64 \\
(7.60)\end{array}$ \\
\hline FL & $\begin{array}{c}24.00 \\
(13.07)\end{array}$ & $\begin{array}{l}-9.78 \\
(7.55)\end{array}$ \\
\hline GA & $\begin{array}{c}8.16 \\
(6.58)\end{array}$ & $\begin{array}{c}-.27 \\
(3.80)\end{array}$ \\
\hline ID & $\begin{array}{c}.16 \\
(18.65)\end{array}$ & $\begin{array}{l}-10.29 \\
(10.78)\end{array}$ \\
\hline IL & $\begin{array}{c}15.60 \\
(10.00)\end{array}$ & $\begin{array}{c}7.04 \\
(5.78)\end{array}$ \\
\hline IN & $\begin{array}{c}6.34 \\
(10.61)\end{array}$ & $\begin{array}{c}.24 \\
(6.13)\end{array}$ \\
\hline IO & $\begin{array}{c}7.55 \\
(13.57)\end{array}$ & $\begin{array}{l}-2.88 \\
(7.84)\end{array}$ \\
\hline $\mathrm{KS}$ & $\begin{array}{c}-3.73 \\
(14.34)\end{array}$ & $\begin{array}{l}-8.59 \\
(8.29)\end{array}$ \\
\hline $\mathrm{KY}$ & $\begin{array}{r}-29.01 * \\
(6.62)\end{array}$ & $\begin{array}{c}4.20 \\
(3.82)\end{array}$ \\
\hline LA & $\begin{array}{l}-4.13 \\
(7.87)\end{array}$ & $\begin{array}{r}-11.79 * \\
(4.55)\end{array}$ \\
\hline ME & $\begin{array}{c}15.66 \\
(11.88)\end{array}$ & $\begin{array}{l}14.21^{*} \\
(6.86)\end{array}$ \\
\hline MD & $\begin{array}{c}18.41 \\
(11.97)\end{array}$ & $\begin{array}{l}-7.08 \\
(6.92)\end{array}$ \\
\hline MA & $\begin{array}{r}36.96^{*} \\
(13.30)\end{array}$ & $\begin{array}{l}22.58 * \\
(7.69)\end{array}$ \\
\hline MI & $\begin{array}{r}29.14 * \\
(19.09)\end{array}$ & $\begin{array}{l}10.74 \\
(6.99)\end{array}$ \\
\hline MN & $\begin{array}{r}36.31 * \\
(12.13)\end{array}$ & $\begin{array}{l}-1.14 \\
(7.01)\end{array}$ \\
\hline MS & $\begin{array}{c}-10.21 \\
(9.97)\end{array}$ & $\begin{array}{c}.30 \\
(5.76)\end{array}$ \\
\hline MT & $\begin{array}{c}-5.37 \\
(18.18)\end{array}$ & $\begin{array}{c}-16.53 \\
(10.50)\end{array}$ \\
\hline $\mathrm{NE}$ & $\begin{array}{l}-47.21^{*} \\
(15.25)\end{array}$ & $\begin{array}{r}-11.78 \\
(8.81)\end{array}$ \\
\hline NV & $\begin{array}{r}40.60 * \\
(20.21)\end{array}$ & $\begin{array}{l}-20.12 \\
(11.68)\end{array}$ \\
\hline
\end{tabular}

\begin{tabular}{|c|c|}
\hline SREV & OEXPb \\
\hline $\begin{array}{l}-39.65^{*} \\
(10.14)\end{array}$ & -4.92 \\
\hline $\begin{array}{r}58.92 * \\
(27.07)\end{array}$ & 9.30 \\
\hline $\begin{array}{c}17.86 \\
(31.26)\end{array}$ & -7.18 \\
\hline $\begin{array}{r}52.31 * \\
(23.54)\end{array}$ & 13.05 \\
\hline $\begin{array}{l}175.97 * \\
(21.92)\end{array}$ & 117.33 \\
\hline $\begin{array}{c}13.30 \\
(21.82)\end{array}$ & -6.79 \\
\hline $\begin{array}{l}-25.93^{*} \\
(10.99)\end{array}$ & -33.93 \\
\hline $\begin{array}{l}-12.50 \\
(31.24)\end{array}$ & -8.54 \\
\hline $\begin{array}{c}.81 \\
(16.68)\end{array}$ & -17.61 \\
\hline $\begin{array}{c}22.47 \\
(17.89)\end{array}$ & 16.93 \\
\hline $\begin{array}{c}-2.34 \\
(22.66)\end{array}$ & -8.74 \\
\hline $\begin{array}{l}-20.81 \\
(23.92)\end{array}$ & -13.64 \\
\hline $\begin{array}{l}-17.01 \\
(11.06)\end{array}$ & 10.32 \\
\hline $\begin{array}{r}27.76 * \\
(13.37)\end{array}$ & 36.61 \\
\hline $\begin{array}{c}17.95 \\
(19.77)\end{array}$ & -3.39 \\
\hline $\begin{array}{r}45.63 * \\
(19.94)\end{array}$ & 30.05 \\
\hline $\begin{array}{r}56.99 * \\
(22.27)\end{array}$ & 11.00 \\
\hline $\begin{array}{r}54.42 * \\
(20.20)\end{array}$ & 20.98 \\
\hline $\begin{array}{r}61.09 * \\
(20.34)\end{array}$ & 25.24 \\
\hline $\begin{array}{c}-7.32 \\
(16.68)\end{array}$ & 2.77 \\
\hline $\begin{array}{l}-38.03 \\
(30.43)\end{array}$ & -26.05 \\
\hline $\begin{array}{l}-37.20 \\
(25.45)\end{array}$ & 14.72 \\
\hline 20.78 & -11.77 \\
\hline
\end{tabular}


Appendix B (continued)

\begin{tabular}{|c|c|c|c|c|}
\hline & $\mathrm{SAE}$ & SWL & SREV & $0 \mathrm{EXP}^{\mathrm{b}}$ \\
\hline $\mathrm{NH}$ & $\begin{array}{l}-13.16 \\
(13.90)\end{array}$ & $\begin{array}{c}8.37 \\
(8.03)\end{array}$ & $\begin{array}{l}-33.65 \\
(23.18)\end{array}$ & -23.84 \\
\hline NJ & $\begin{array}{l}16.68 \\
(10.66)\end{array}$ & $\begin{array}{c}4.74 \\
(6.16)\end{array}$ & $\begin{array}{c}-.53 \\
(17.89)\end{array}$ & -19.11 \\
\hline NM & $\begin{array}{c}31.28 \\
(17.47)\end{array}$ & $\begin{array}{c}-25.58 * \\
(10.09)\end{array}$ & $\begin{array}{c}79.72 * \\
(29.23)\end{array}$ & 58.67 \\
\hline NY & $\begin{array}{c}57.49 * \\
(10.43)\end{array}$ & $\begin{array}{l}16.29 * \\
(6.03)\end{array}$ & $\begin{array}{c}86.08 * \\
(17.51)\end{array}$ & 22.07 \\
\hline $\mathrm{NC}$ & $\begin{array}{l}27.59 * \\
(6.72)\end{array}$ & $\begin{array}{c}3.93 \\
(3.89)\end{array}$ & $\begin{array}{c}3.18 \\
(11.28)\end{array}$ & -25.98 \\
\hline ND & $\begin{array}{l}-41.82 \star \\
(12.12)\end{array}$ & $\begin{array}{r}-18.44^{\star} \\
(7.01)\end{array}$ & $\begin{array}{c}-8.53 \\
(20.33)\end{array}$ & 40.67 \\
\hline $\mathrm{OH}$ & $\begin{array}{c}26.56 * \\
(11.02)\end{array}$ & $\begin{array}{c}3.87 \\
(6.37)\end{array}$ & $\begin{array}{c}-5.96 \\
(18.44)\end{array}$ & -34.07 \\
\hline $\mathrm{OK}$ & $\begin{array}{r}-11.22 \\
(9.41)\end{array}$ & $\begin{array}{l}-6.61 \\
(5.44)\end{array}$ & $\begin{array}{c}2.93 \\
(15.72)\end{array}$ & 16.79 \\
\hline OR & $\begin{array}{c}15.35 \\
(14.06)\end{array}$ & $\begin{array}{c}1.49 \\
(8.13)\end{array}$ & $\begin{array}{c}33.70 \\
(23.49)\end{array}$ & 17.75 \\
\hline PA & $\begin{array}{l}30.86^{*} \\
(9.46)\end{array}$ & $\begin{array}{l}13.01^{*} \\
(5.47)\end{array}$ & $\begin{array}{r}40.97 * \\
(15.89)\end{array}$ & 4.91 \\
\hline $\mathrm{RI}$ & $\begin{array}{c}11.27 \\
(12.36)\end{array}$ & $\begin{array}{l}28.30 * \\
(7.14)\end{array}$ & $\begin{array}{r}56.12^{\star} \\
(20.85)\end{array}$ & 33.53 \\
\hline SD & $\begin{array}{l}-59.14 * \\
(14.18)\end{array}$ & $\begin{array}{r}-16.89 * \\
(8.19)\end{array}$ & $\begin{array}{c}-87.87 * \\
(23.71)\end{array}$ & -21.97 \\
\hline $\mathrm{TN}$ & $\begin{array}{r}-23.59 * \\
(6.39)\end{array}$ & $\begin{array}{c}3.53 \\
(3.69)\end{array}$ & $\begin{array}{l}-38.13 \\
(10.65)\end{array}$ & -15.95 \\
\hline UT & $\begin{array}{r}64.74 * \\
(22.27)\end{array}$ & $\begin{array}{l}-16.00 \\
(12.87)\end{array}$ & $\begin{array}{c}50.97 \\
(37.30)\end{array}$ & -7.37 \\
\hline VT & $\begin{array}{c}9.89 \\
(15.93)\end{array}$ & $\begin{array}{c}9.61 \\
(9.21)\end{array}$ & $\begin{array}{c}36.94 \\
(26.53)\end{array}$ & 23.21 \\
\hline VA & $\begin{array}{l}-5.73 \\
(8.44)\end{array}$ & $\begin{array}{r}-11.54 * \\
(4.88)\end{array}$ & $\begin{array}{l}-19.72 \\
(14.07)\end{array}$ & -9.37 \\
\hline WA & $\begin{array}{c}46.83^{*} \\
(17.23)\end{array}$ & $\begin{array}{l}-5.93 \\
(9.96)\end{array}$ & $\begin{array}{c}71.54 * \\
(28.77)\end{array}$ & 27.08 \\
\hline WI & $\begin{array}{c}6.68 \\
(10.82)\end{array}$ & $\begin{array}{c}8.59 \\
(6.25)\end{array}$ & $\begin{array}{c}76.81^{*} \\
(18.18)\end{array}$ & 66.69 \\
\hline WY & $\begin{array}{c}-1.96 \\
(25.27)\end{array}$ & $\begin{array}{l}-24.79 \\
(14.60)\end{array}$ & $\begin{array}{c}34.73 \\
(42.30)\end{array}$ & 46.61 \\
\hline
\end{tabular}

Standard errors are in parentheses.

* Indicates significance at the $5 \%$ level.

a These estimates are from the model presented in Table 1. Seven states are excluded: Alabama is the base state, Arizona and Texas have no observations, Missouri and South Carolina have only one observation, and Alaska and Hawail have unique fiscal situations which suggest excluding them from our general analysis.

b Calculated from the point estimates. 